\title{
A DRIFTED FLORA FROM THE KIMMERIDGIAN (UPPER JURASSIC) OF LOTHBEG POINT, SUTHERLAND, SCOTLAND
}

\author{
J. VAN DER BURGH and J.H.A. VAN KONIJNENBURG-VAN CITTERT \\ Laboratory of Palaeobotany and Palynology, State University, Utrecht (The Netherlands)
}

(Received April 10, 1984 ; revised version accepted June 28, 1984)

\begin{abstract}
Van der Burgh, J. and Van Konijnenburg-van Cittert, J.H.A., 1984. A drifted flora from the Kimmeridgian (Upper Jurassic) of Lothbeg Point, Sutherland, Scotland. Rev. Palaeobot. Palynol., 43: 359-396.

Plant remains, mainly occurring as leaf compressions, from Kimmeridgian strata exposed along the coast of northeastern Scotland are identified and described briefly. They include 19 species, representing 14 genera. One new species, attributed to the conifers, is formally described: Taxodiophyllum scoticum gen. et $\mathrm{sp}$. nov. A count of the material is made and the ecology of the flora is discussed.
\end{abstract}

\section{INTRODUCTION}

Jurassic beds are exposed as scars at beach level and partly also as cliffs along the coast of northeastern Scotland, from Kintradwell in the south west to Helmsdale in the northeast. They include the "classic" plant fossil localities of Brora (Stopes, 1907; Harris and Rest, 1966) and Culgower (Seward, 1911). The Brora locality is now known to be of Lower Callovian, Bathonian age whilst that at Culgower is Kimmeridgian (Lam and Porter, 1977).

A number of other localities on that stretch of coast have also yielded plant remains, though in general the material is scarce and fragmented. They have thus been neglected and none has hitherto been described. Three localities, however, have yielded sufficient material from recent collecting for serious study: Kintradwell (NC 925 074), Lothbeg Point (NC 962 096) and Krakaig links (NC 968 100).

The main aims of this paper are twofold: to describe the plants from these localities with special reference to their cuticular characters, and to deduce something about their ecological environment. The matrix is a dark grey shale with numerous remains of cephalopods and bivalve molluses as well as small fragments of plants. One of the ammonites, Aulacostephanoides $\mathrm{cf}$. mutabilis (J. Sowerby), determined by D. Phillips, British Museum (Natural History), dates the beds as Lower Kimmeridgian, see also Lam and Porter (1977). The occurrence of well-preserved but fragmentary plant material with such a rich and diverse fully marine fauna suggests strong drifting of the 
plants into a fully marine environment. Although in general in Jurassic rocks plants do occur drifted out into such environments, they are rarely so abundant or well preserved as here. The environment of deposition was evidently unusual, as has been indicated by sedimentological study of the area in recent years, which points to a submarine delta model of sedimentation involving turbidity flows, resulting in subwave-base marine shales interbedded with boulder beds and sand flows (Selley, 1975).

\section{METHODS}

The plant fragments have been studied macroscopically and by cuticular analysis. Drawings (of the fern material) have been made to show the vein pattern clearly and photographs have been made of the best specimens. The specimens and slides are all in the collections of the Laboratory of Palaeobotany and Palynology, Utrecht under the numbers 13175-13225, 13456$13460,13508-13568$ and 14153-14181, with representative duplicate material in the British Museum (Natural History).

\section{SYSTEMATIC DESCRIPTIONS}

The following species have been identified:

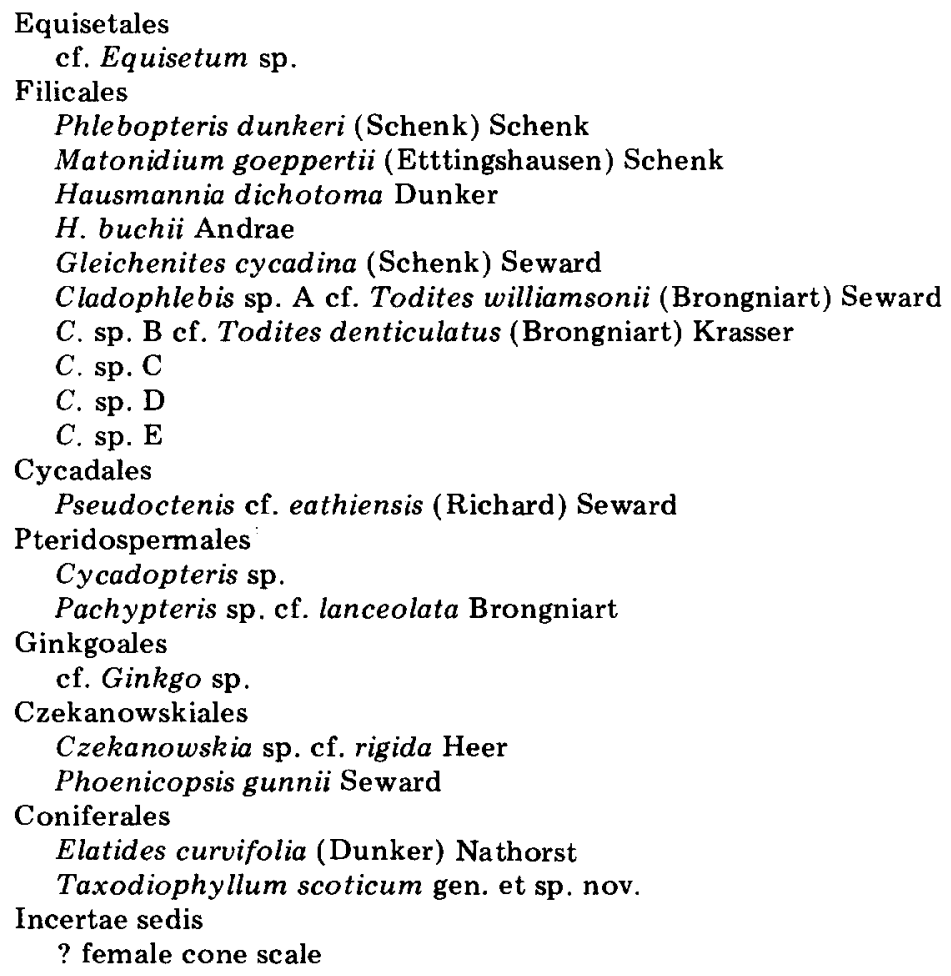


Order EQUISETALES

\title{
Genus Equisetum Linnaeus 1753
}

\author{
cf. Equisetum sp. (Plate I, 1)
}

Material studied: Coll. no.13193, 13205, 13206, 14158.

Description: These are narrow (less than $10 \mathrm{~mm}$ wide) ribbed stems, apparently material from internodes only.

Discussion: As no nodal material is available, no secure identification of a genus is possible. We have referred our material to possibly Equisetum mainly on the base of its relative abundance in Upper Jurassic strata.

Ecology: Equisetum is known at the present day from a wide range of habitats. In Jurassic and Wealden deposits many species are known in situ, growing in conditions that clearly were wet. Very often the stems formed mass growths in apparently shallow water or on wet soil (Harris, 1961).

Order FILICALES

Family MATONIACEAE

\section{Genus Phlebopteris Brongniart 1836}

Phlebopteris dunkeri (Schenk) Schenk (Plate I, 2-4) (Fig.1)

Material studied: Coll. no.13175-13179, 13196, 13199, 13205, 13209, $13210,13213,13215-13217,13220-13222,13224,13460,13520,14155$, 14157, 14162, 14172, 14179, 14181.

Description: This fern is mainly found as fragments of isolated more or less lanceolate pinnules. The greatest measured length for a pinnule was $52 \mathrm{~mm}$. The base and the apex are often lacking. The width of the pinnules is up to $6.5 \mathrm{~mm}$, tapering towards the apex, which is about $2 \mathrm{~mm}$ wide and obtuse in shape.

The midrib bears lateral veins at intervals of about $1 \mathrm{~mm}$. These fork near the midrib into forward and backward branches. The forward branches frequently unite with a backward branch of the next lateral vein, forming an arch which gives off some outward branches. These divide and anastomose once or twice forming a reticulate pattern which extends to the margin. In fertile pinnules the sori are supplied by a forward branch of the branch systems. Inside the arch sometimes a weak venation can be observed. Besides the bulging dome of lamina over the sori in the pinnule or in the impressions in the matrix, nothing of sporangia or placentae could be observed. Three blocks showed fragments of pinnules attached to a rachis fragment (13175, 13221,14181 ). From these it is clear that the basal web of lamina along the rachis is narrow. No venation could be observed in it.

Discussion: All the material of this species was found preserved as fusain. This species is one of the most numerous fossils in the flora. Seward (1911) 


\section{PLATE I}
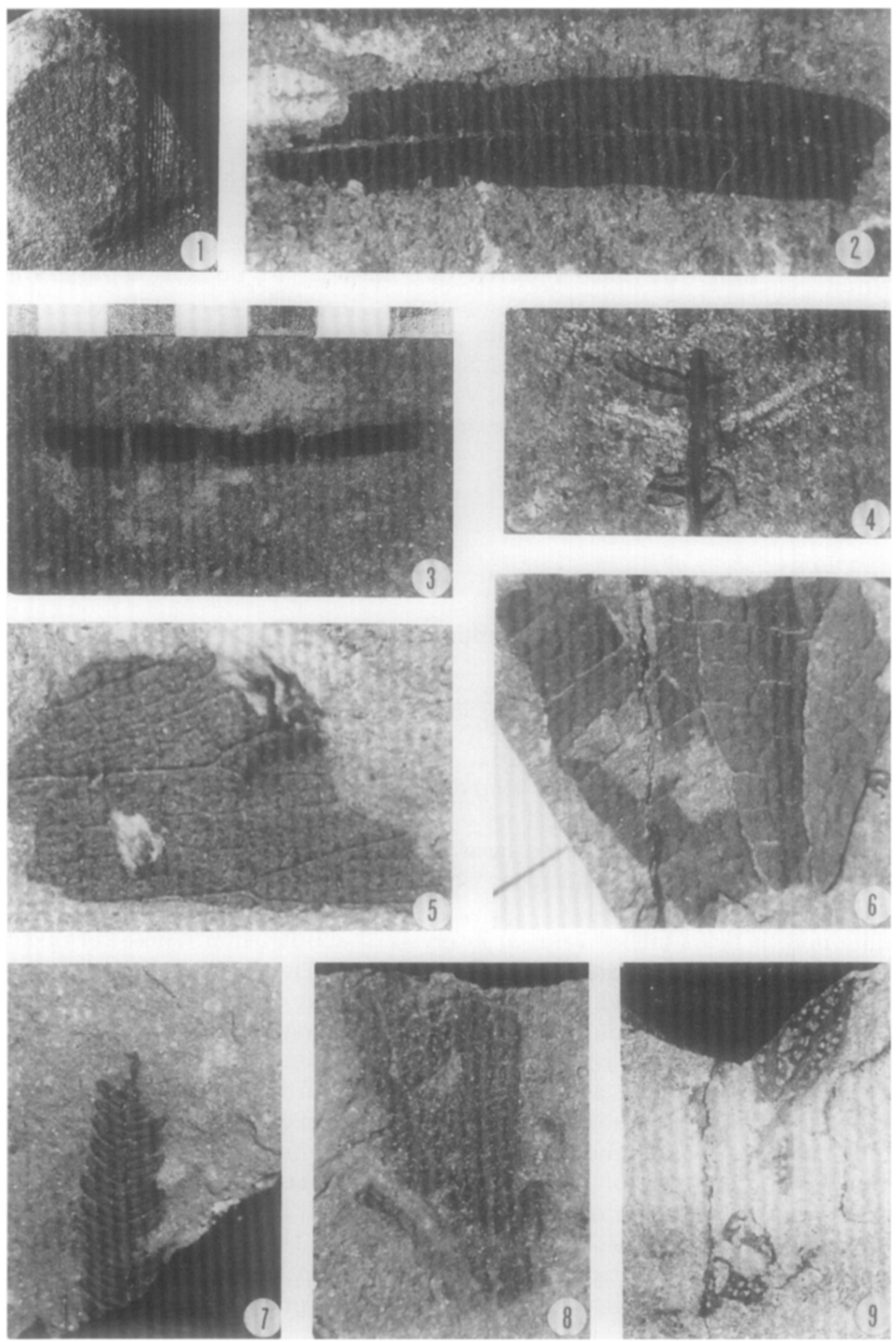

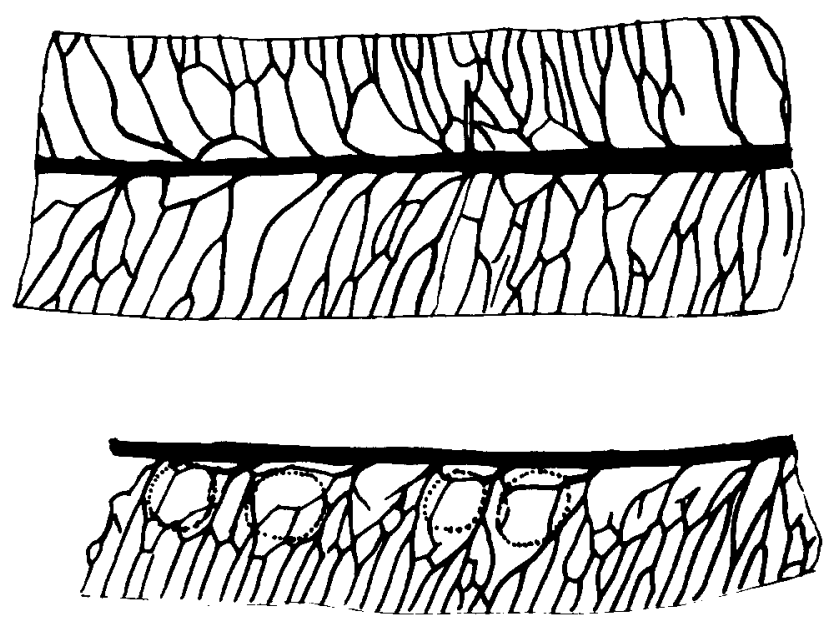

Fig.1. Phlebopteris dunkeri (Schenk) Schenk, fertile specimen no.13178B, sterile specimen no. $13176, \times 5$.

described Laccopteris dunkeri from Culgower Bay, which is a synonym of Phlebopteris dunkeri. Although there is also a similarity with $P$. woodwardii Leckenby, the species differ according to Harris (1961) in the position of the sori, which are close to the midrib in $P$. woodwardii and nearer the middle of the half lamina in $P$. dunkeri. They also differ in the branches of the lateral veins, which form isodiametric or slightly elongate meshes in $P$. dunkeri and elongated meshes in $P$. woodwardii; and within the arch there is venation formed by the primary branches of the lateral veins in $P$. dunkeri which is absent from $P$. woodwardii. Our material has therefore been attributed to $P$. dunkeri mainly on the basis of its weak venation inside the vein arch. The pinnules of $P$. dunkeri are often larger in size than those of $P$. woodwardii.

The stratigraphic range of the species is from Liassic to Lower Cretaceous in Europe.

Ecology: This species is normally found as fusain, therefore it is considered to be a plant of inland heaths (Harris, 1961, 1981).

\section{PLATE I}

1. cf. Equisetum sp., no.13191, $\times 1$.

2-4. Phlebopteris dunkeri (Schenk) Schenk: 2, no.13178A, fertile, $\times 2.5 ; 3$, no.14172A, sterile, $\times 1 ; 4$, no.14181, rachis with pinnules, $\times 1$.

5, 6. Hausmannia buchii Andrae: 5, no.13211A, $\times 2.5 ; 6$, no.13181B, $\times 2.5$.

7. Matonidium goeppertii (Ettingshausen) Schenk, no.13208, $\times 2$.

8, 9. Hausmannia dichotoma Dunker: 8 , no.13218, sterile, $\times 2 ; 9$, no.13554, fertile, $\times 2$. 


\section{Genus Matonidium Schenk 1871}

Matonidium goeppertii (Ettingshausen) Schenk (Plate I, 7)

Material studied: Coll. no.13208, 14159.

Description: Only two small sterile fragments were collected, from Lothbeg Point, the longest $20 \mathrm{~mm}$ long and $7 \mathrm{~mm}$ wide. They consist of portions of ultimate pinnae with pinnules. The pinnules are falcate, about $1.2 \mathrm{~mm}$ broad, tapering to the apex and often almost in contact. The margins are entire, the midrib rather prominent and the lateral veins fork once or twice. There are no anastomoses between the veins. Along the pinna axis the pinnules are webbed.

Discussion: This material, like that of Phlebopteris dunkeri, is also preserved as fusain. It is identical in all preserved characters to $M$. goeppertii from the Wealden (Schenk, 1871), from the Yorkshire Jurassic (Harris, 1961) and to material recorded previously from Sutherland (Seward, 1911; Harris, 1961). This species ranges from the Middle Jurassic to Lower Cretaceous of Europe. Ecology: From the numerous finds in the German Wealden coal it may be deduced that $M$. goeppertii was a peat-inhabiting plant or at least that it occurred in moist circumstances. This is supported by its occurrence in the Yorkshire Jurassic where it is associated with normally local floras. Sometimes it has been found as fusain (Harris, 1961), as in our case, which might point to dry circumstances. There is a difference however from Phlebopteris woodwardii, which is always preserved as fusain, and $P$. dunkeri, which is mainly preserved as fusain. Therefore, it is considered a plant that grew under normally wet, possibly also oligotrophic (peat) conditions.

Family DIPTERIDACEAE

\section{Genus Hausmannia Dunker 1846}

Hausmannia dichotoma Dunker (Plate I, 8, 9)

Material described: Coll. no.13192, 13218, 13225, 13554.

Description: Four fragments show portions of lamina with strongly marked longitudinal veins dividing dichotomously. These are connected by a meshwork of secondary veins, the meshes of which tend to be more or less rectangular. Some of the longitudinal secondary veins are intermediate in thickness between the main veins and the transverse secondary veins. In the largest specimen (13192) only the repeatedly dichotomising large veins could be observed. This fragment is $70 \mathrm{~mm}$ long, the width at the base is $3 \mathrm{~mm}$ and at the apex about $30 \mathrm{~mm}$. It shows a rachis. The other fragments are smaller. The fertile fragment (13554) differs from the sterile fragments in the hollowed areas where sori are presumed to have been present originally but have either fallen out or have been abraded. Details of sori not known.

Discussion: The material is similar to that of Seward (1911) from Culgower 
and of Harris (1961) from Yorkshire. As it is fragmentary, it is identified mainly on the very typical shape of the hollow areas in the lamina of the fertile specimen. $H$. dichotoma was described from the Wealden of Germany as the type species of the genus Hausmannia (Dunker, 1846; Schenk, 1871). The stratigraphical range of the species in Europe is Lower Jurassic to Lower Cretaceous.

Ecology: In Yorkshire $H$. dichotoma is known from three localities. In two of them it occurs together with Pachypteris and marine organisms in reasonable quantities, in the third it is rather rare. In the Wealden deposits, where a distinct marine influence has been found, it is rather abundant. Therefore, it is considered to grow in the neighbourhood of the coast under rather moist, possibly brackish circumstances.

Hausmannia buchii Andrae (Plate I, 5, 6)

Material studied: Coll. no.13180, 13181, 13211, 13559, 14160, 14173.

Description: This material consists of several fragments of lamina. They show strong veins with connecting secondary veins, which arise almost at right angles. In two fragments the main veins are forked.

Discussion: Strong veins with connecting secondary veins at right angles to them are found in both Clathropteris and Hausmannia. In Clathropteris, however, the main veins do not fork and therefore this material must be identified with Hausmannia. Within the genus a fair similarity exists with H. buchii, as described by Seward (1911).

H. buchii has been described as the type species of the genus Protorhipis by Andrae (1853). This genus has been included as the subgenus Protorhipis in the genus Hausmannia by Oishi and Yamasita (1935) after an earlier study which united the genera completely (Richter, 1906). The species of this subgenus have a somewhat older geological range than the species of the subgenus Hausmannia and as a whole it is considered more primitive. The world geological range of $H$. buchii is Lower Jurassic to possibly Lower Cretaceous. Ecology: H. buchii is known from marine deposits or deposits with marine influence (Andrae, 1853; Seward, 1911; Carpentier, 1927) and therefore is considered a plant from wet coastal, brackish localities. The worldwide distribution of the very limited number of localities from which this species is known also favours this interpretation.

\section{Family GLEICHENIACEAE}

\section{Genus Gleichenites Goeppert 1836}

\section{Gleichenites cycadina (Schenk) Seward (Plate II, 1, 2)}

Material studied: Coll. no.13182-13187, 13199-13206, 13209, 13213$13215,13219,13220,13222,13225,13508,13521,13526,13550,13555$, 13556, 13568, 14154, 14156, 14167, 14168, 14173, 14178, 14179. 
Description: The material consists of numerous tiny fragments of ultimate pinnae bearing pinnules. One fragment (13187) consists of a short pinna with very short attached ultimate pinnae, each having only one or two fully developed pinnules and an end lobe. On some other pinnae the pinnules are crenulate, forming intermediates between these composite parts and the normal ultimate pinnae bearing single pinnules with entire margins. The shape of the pinnules ranges from suborbicular to elongated with a rounded apex and constricted base. The basiscopic part of the pinnule base forms a distinct lobe. The venation is katadromic. The midrib gives off forked lateral veins, sometimes visible as sharply marked grooves in the surface of the pinnules. Despite compression, the substance is still very thick and from this the lamina was evidently thick and leathery originally. In a fertile specimen (13185) the sori are borne parallel to the midrib and about halfway between the midrib and the margin of the pinnule. There are up to ten sori per pinnule, visible as dome-shaped bulgings in the upper surface. Sporangia could not be seen.

Discussion: This material is similar to that described by Seward (1911) from Culgower Bay, also to the material described by Carpentier (1927) from the Wealden of northern France and by Schenk (1871) from the German Wealden. Material of several Russian and northern Asiatic localities has been mentioned under the name Gleichenia cycadina. As far as can be judged from plates and descriptions, they all bear a reasonable similarity to our material. Under the name Gleichenites nordenskiöldii Heer, Fontaine (1889) described some material from the Potomac Formation of North America. The pinnules however are not constricted at the base and no basiscopic lobe is present. Appert (1973) described material from Madagascar under the name Gleichenites nordenskiöldii (Heer) Seward. Although there is a strong similarity with our material, there is also a difference in that the angle between the pinnules and the pinna is smaller than in our material. Appert remarked that some of the material from Culgower Bay might belong to G. nordenskiöldii and not to G. cycadina, as described by Seward (1911). The species $G$. cycadina and $G$. nordenskiöldii show a considerable overlap on their characters and could possibly be united. As our material is not sufficiently comprehensive for comparing all characters, no attempt in this direction has been made. Ecology: According to Schenk this species is found mainly in the coal-

PLATE II

1, 2. Gleichenites cycadina (Schenk) Seward: 1 , no.13201, sterile, $\times 2 ; 2$, no.13185, fertile, $\times 2$.

3, 4. Cladophlebis sp. A cf. Todites williamsonii (Brongniart) Seward: 3, no.13188B, $\times 2.5 ; 4$, no. $14180, \times 1.5$.

5, 6. Cladophlebis sp. B cf. Todites denticulatus (Brongniart) Krasser: 5, no.13194A, $\times 2 ; 6$, no.13559B, $\times 2.5$.

7, 8. Cladophlebis sp. C: 7 , no.13564, $\times 2 ; 8$, no.13212, $\times 1$.

9. Cladophlebis sp. D, no.13191, $\times 3$.

10. Cladophlebis sp. E, no.13188A, $\times 1.5$. 


\section{PLATE II}
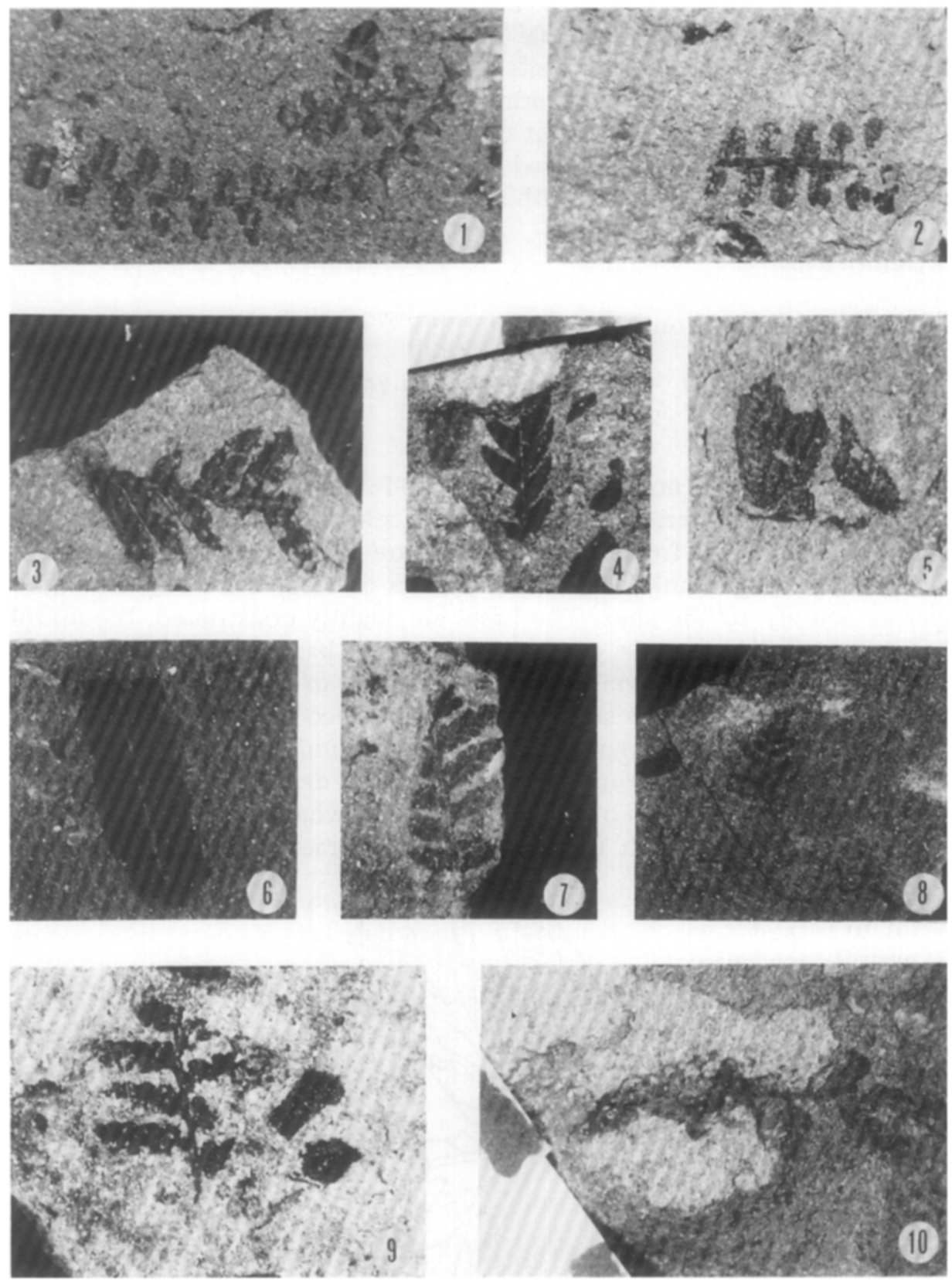
bearing shales of the Wealden of northern Germany. Therefore, we may assume it lived in a moist habitat. The leathery pinnules however are a mark of xerophylly which would enable this plant to live under xerophytic circumstances. In the Wealden deposits there is a marked marine influence. The source of our material is also marine with much continental debris, from which we may expect a high input of coastal plant material. We may therefore conclude that $G$. cycadina lived in brackish swamps and hence exhibited a combination of moist habitat with xerophylly.

\section{Unclassified ferns}

\section{Genus Cladophlebis Brongniart 1849}

Cladophlebis sp. A cf. Todites williamsonii (Brongniart) Seward (Plate II, 3, 4) (Fig.2)

Material studied: Coll. no.13188b, 13189, 13459, 13559a, 14180.

Description: The material consists of small sterile fragments. The pinnules arise at an acute angle from the rachis, they are rather straight, $8 \mathrm{~mm}$ long or longer (exact length unknown as the apex is lacking), with entire margins, tapering acutely to the apex. The bases are slightly constricted, the midrib arising near the basiscopic edge and branching katadromically, giving off numerous twice-forked lateral veins which arise at an acute angle $\left(30-40^{\circ}\right)$.

Discussion: The material is similar to that described by Seward (1911) from Culgower Bay under the name Todites williamsonii, but the fragments are much smaller. It differs from $T$. williamsonii as described from Yorkshire (Harris, 1961) in the length of the pinnules (somewhat larger in our material) and in the angle at which they arise from the rachis (right angles in the

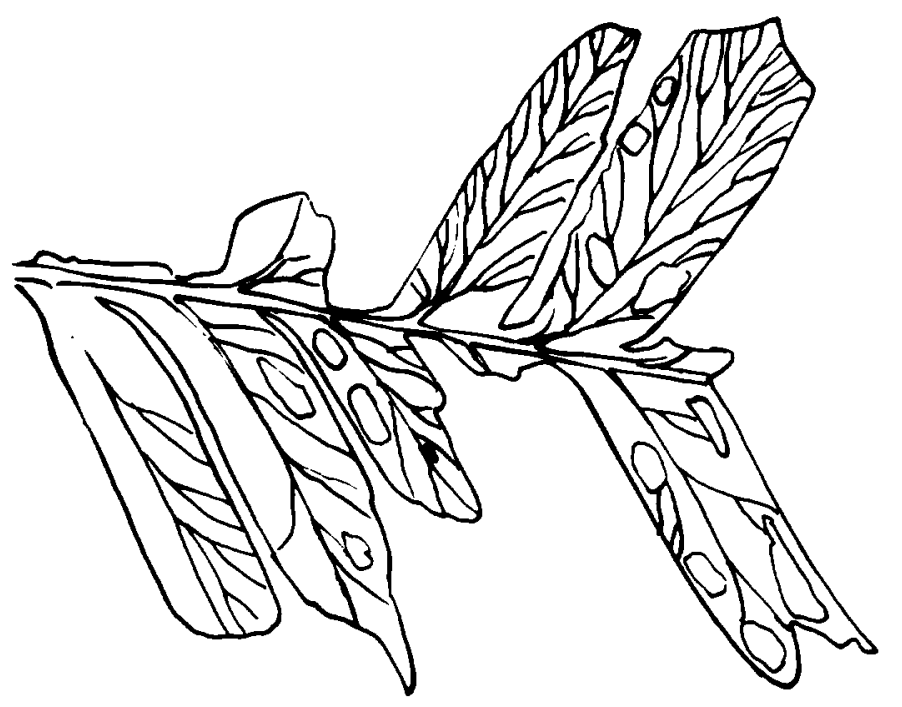

Fig.2. Cladophlebis sp. A cf. Todites williamsonii (Brongniart) Seward, no.13188B, $\times 5$. 
Yorkshire material, always smaller angles in our material). Thus, the identity with $T$. williamsonii is somewhat open and this material is therefore named Cladophlebis sp. A. Stopes (1907) reported T. williamsonii from Brora, although she gave neither a description nor a figure.

Ecology: Based on the occurrence of T. williamsonii in Yorkshire, Cladophlebis sp. A was probably a plant of moist, rather lush vegetation.

Cladophlebis sp. B cf. Todites denticulatus (Brongniart) Krasser (Plate II, 5,6) (Fig.3).

Material studied: Coll. no.13194a, 13559b.

Description: Two fragments of sterile pinnules. The first, 13194 , is a rather short and broad pinnule, with a distinct midrib, giving off katadromically several more or less parallel secondary veins. These fork once towards the margin and arise at an angle of $45^{\circ}$. The margin is very slightly dentate. The other, $13559 \mathrm{~b}$, is a tiny fragment of a dentate pinnule with a well-marked midrib and rather long, once or twice forked, lateral veins. These laterals arise at an acute angle from the midrib. Some of them end in the marginal teeth.

Discussion: These fragments, though differing in their margin, have the same venation pattern and therefore may be taken together. We tentatively compare them with Todites denticulatus. This fern has pinnules with wide bases and once-forked lateral veins with only the basal lateral veins forked twice. Since our pinnules are both incomplete, a secure identification to this species is impossible.

Cladophlebis denticulatus has been mentioned by Stopes (1907) and Seward (1911) for Brora and Culgower, respectively. Figure 32 on plate II of Seward bears some likeness to our material, apart from the only once-forked lateral veins.

Ecology: Todites denticulatus is known from locally deposited floras in Yorkshire (Harris, 1961), therefore it is considered as a plant growing in lush vegetation under moist circumstances.

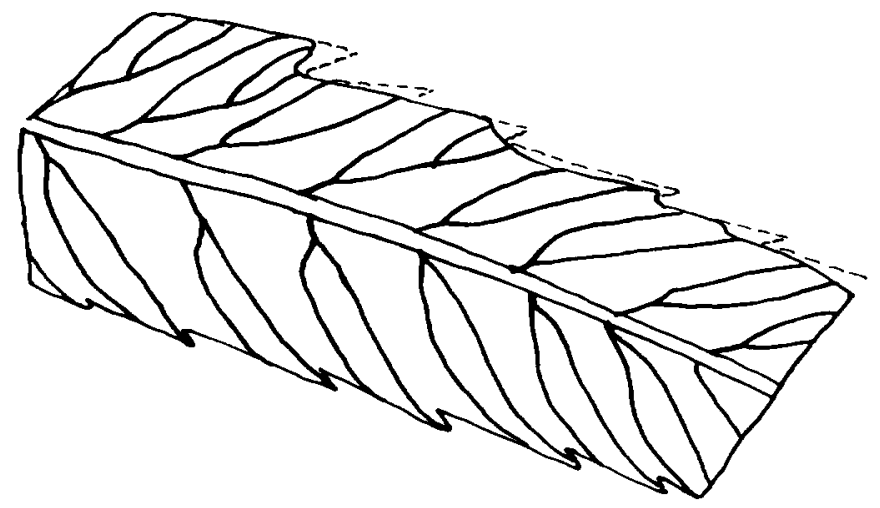

Fig.3. Cladophlebis sp. B cf. Todites denticulatus (Brongniart) Krasser, no.13559B, $\times 5$. 
Cladophlebis sp. C (Plate II, 7, 8) (Fig.4)

Material studied: Coll. no.13190, 13212, 13551, 13552, 13561, 13564, 13565.

Description: The material consists of very small fragments of pinna apices with adhering katadromic pinnules. The biggest pinnules are $5 \mathrm{~mm}$ long and strongly lobed. Traces of a midrib with undivided lateral veins have been observed. The compressions are rather thick and therefore a rather thick lamina may have been present. The pinnule bases are slightly constricted.

Discussion: It was not possible to identify this material with any known species, though there is a superficial resemblance to Aspidistes thomasii Harris in the dimensions and venation of the pinnules. Lovis (1975) remarked that Aspidistes is one of the very few well-described Mesozoic ferns belonging either to the Polypodiaceae or Thelypteridaceae. As one of the oldest known members of these families, it is a pity that lack of evidence prohibits identification of the present material with it.

Ecology: Aspidistes has been found mostly in the Gristhorpe plant bed in Yorkshire, a locality with a predominantly local flora. It is therefore considered to be a plant of moist, lush vegetation.

Cladophlebis sp. D (Plate II, 9) (Fig.5)

Material studied: Coll. no.13191

Description: This is a very small sterile specimen, consisting of apices of pinnae with adhering katadromic pinnules. The rachis has a tendency to follow a zigzag course. The pinnules are strongly lobed, the lobes rather narrow and with wide intervals between them. The bases of the pinnules are strongly constricted. The pinnule midrib gives off once- or twice-forked lateral veins into the lobes.

Discussion: This fern is superficially similar to Cladophlebis sp. C, but differs in the strongly constricted bases of the pinnules and the narrow, widely spaced lobes. It has not been possible to identify this fern with any known species.

Ecology: The ecology of this fern is unknown.

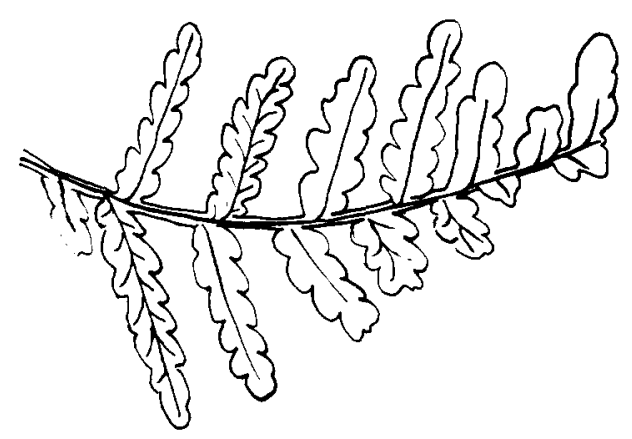

Fig.4. Cladophlebis sp. C, no.13212, A, B, ×5. 


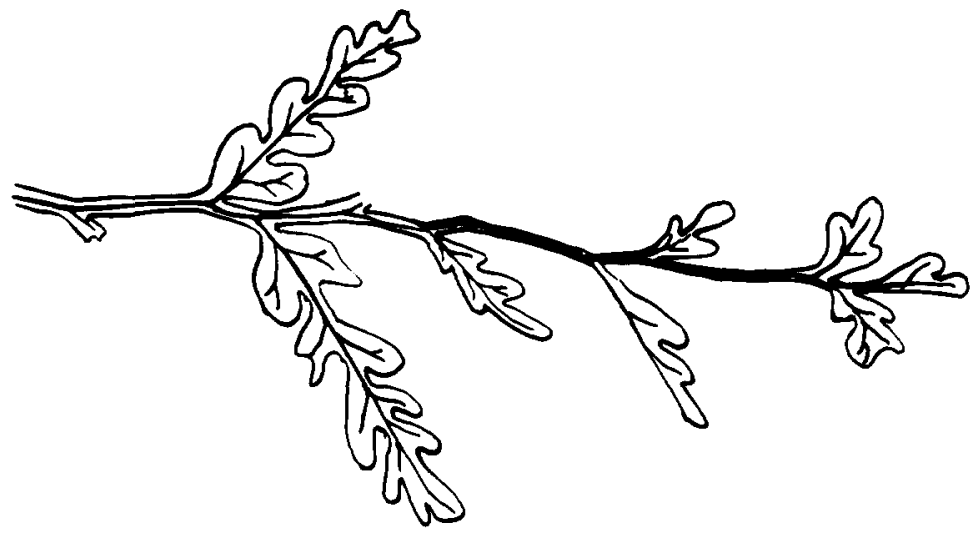

Fig.5. Cladophlebis sp. D, no.13191, A, B, $\times 5$.

Cladophlebis sp. E (Plate II, 10) (Fig.6)

Material studied: Coll. no.13188a, 13207.

Description: These are small fragments of pinnae with attached pinnules which are lobed. The bases are strongly constricted, the basiscopic lobes slightly smaller than the apiscopic ones. Venation anadromic. The midrib of the pinnules gives off laterals at an acute angle, the laterals forking up to four times. The branches sometimes anastomose, forming a meshwork. Discussion: This fern is as yet unidentifiable, despite its anadromic venation. Ecology: The ecology of this fern is unknown.

Order CYCADALES

\section{Genus Pseudoctenis Seward 1911}

Pseudoctenis cf. eathiensis (Richard) Seward (Plate III, 1, 2, 4)

Material studied: Coll. no.13195, 13555, 14164.

Description: There are three blocks showing Pseudoctenis fragments from Lothbeg Point. One has a fragmentary pinna, $39 \times 4.5-6.0 \mathrm{~mm}$, with seven veins. The second has a fragmentary pinna $46 \times 5 \mathrm{~mm}$ with six veins, and the third has two parallel pinnae fragments, both about $30 \mathrm{~mm}$ long and 7-9 $\mathrm{mm}$ wide with respectively nine and ten veins. All three specimens yielded small, rather badly preserved hypostomatic cuticle fragments, 1-2 $\mu \mathrm{m}$ thick. The upper cuticle shows uniform polygonal cells, not forming rows, veins not recognisable. The lower cuticle also shows polygonal cell outlines, tending to form rows, veins not recognisable, stomata evenly and thinly scattered with a tendency to form longitudinal files. Stomata longitudinally or obliquely orientated. Guard cells deeply sunken, stomatal pit usually broad, round or irregular, formed by one or two lateral subsidiary cells and one terminal cell at each end. 


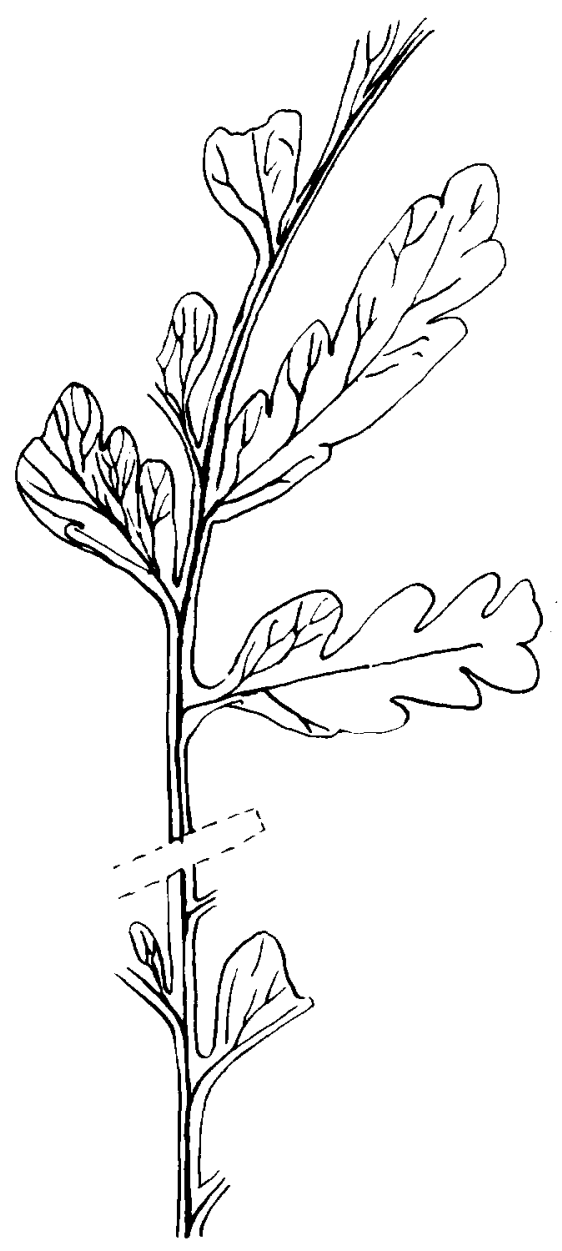

Fig.6. Cladophlebis sp. E, no.13188A, $\times 5$.

Discussion: When Seward created the genus Pseudoctenis in 1911, he named Pseudoctenis eathiensis as type-species, but did not give a diagnosis, only a short description. Since then the original specimens have been studied by Harris (1964), but unfortunately the cuticle of the original specimens is unknown and there is no hope that it will ever become known. So our fragments can only be attributed to this species on macroscopic characters. Although fragmentary, the cuticles agree with those of the much larger

\section{PLATE III}

1, 2, 4. Pseudoctenis cf. eathiensis (Richard) Seward: 1, no.13555, cuticle fragment showing stoma, $\times 200 ; 2$, no.13555, $\times 2 ; 4$, no.14164, cuticle fragment, $\times 200$.

$3,5,6$. Cycadopteris sp.: 3 , no.13519, $\times 2 ; 5$, no.13519, cuticle fragment showing margin, $\times 200 ; 6$, no.13519, cuticle fragment, $\times 200$. 


\section{PLATE III}
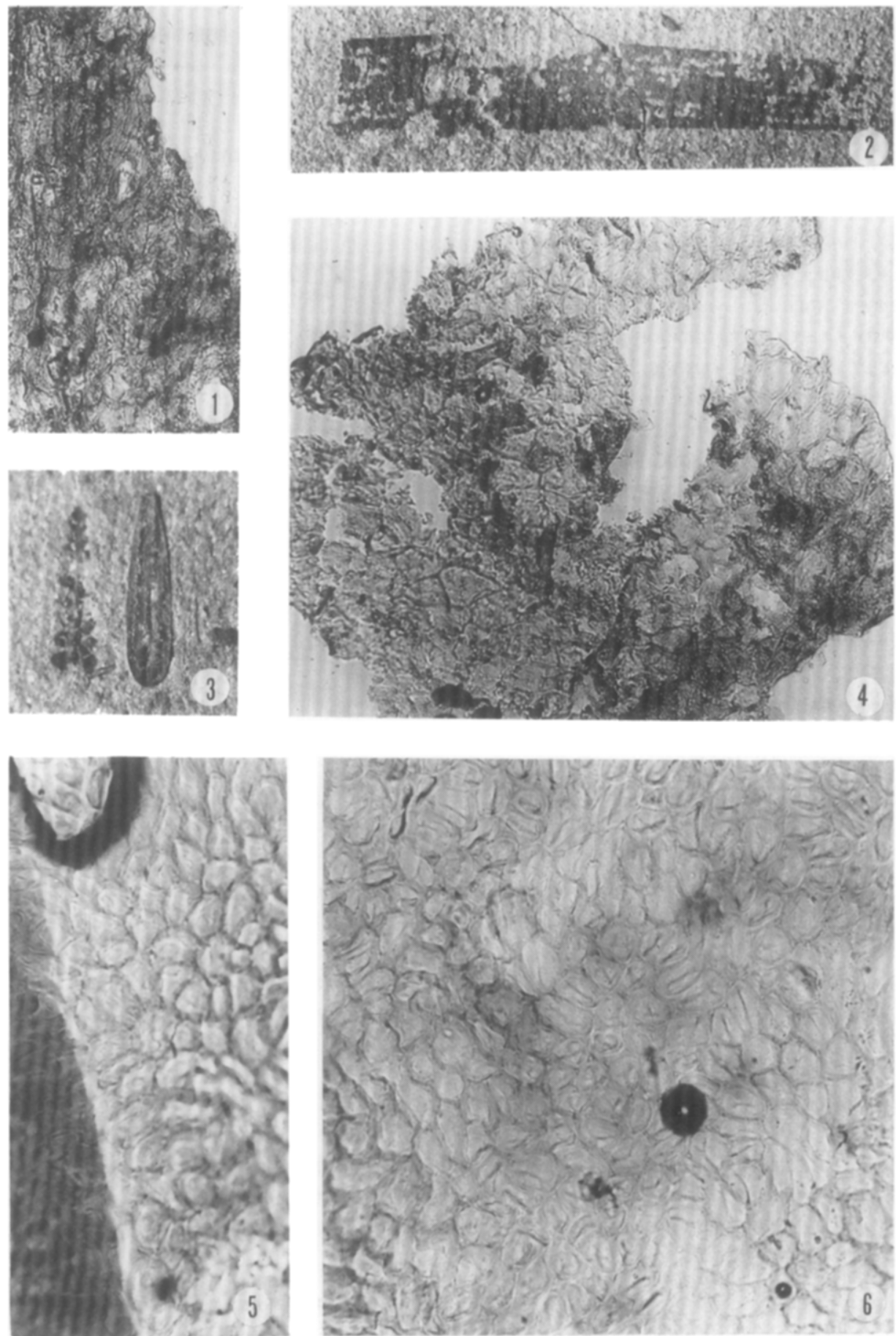
Pseudoctenis specimens from Culgower (quite near Lothbeg Point) and the latter specimens (collected by one of us from Culgower) agree perfectly with the material of $P$. eathiensis as described and figured by Seward (1911). Hence our determination of the Lothbeg Point specimens.

Within Pseudoctenis, $P$. eathiensis resembles most closely $P$. lanei Thomas, differing mainly in having fewer veins per $\mathrm{cm}(10-14$ in $P$. eathiensis and 15-23 in $P$. lanei) and in the angle at which the pinnae arise from the rachis $\left(60-90^{\circ}\right.$ in $P$. eathiensis and $30-70^{\circ}$ in $P$. lanei). There is a possibility that $P$. eathiensis and $P$. lanei are extremes of one species. $P$. aff. eathiensis has also been recorded from the Late Jurassic flora of Georgia, U.S.S.R., with a preserved cuticle (Doludenko and Svanidze, 1969, plate 28,1-5) which agrees with the cuticle yielded by our material. Their cuticle seems to differ from that of $P$. lanei in having no papillae on the ordinary epidermal cells, but $P$. lane $i$ sometimes also lacks such papillae (Dr. C.R. Hill, pers. commun.) leaving no difference in the cuticle.

Ecology: Based on the occurrence of Pseudoctenis in Yorkshire, where it is found mainly in localities reflecting moist, sometimes possibly marine influenced vegetation, we suppose it to be a plant of similar habitats, also on the edge of the land, often forming part of lush vegetation.

\section{Order PTERIDOSPERMALES}

\section{Genus Cycadopteris Zigno 1853}

Cycadopteris sp. (Plate III, 3, 5, 6)

Material studied: Coll. no.13519.

Description: Only one pinnule of a Cycadopteris leaf is represented in our material. It is $14 \mathrm{~mm}$ long and $3 \mathrm{~mm}$ wide at its widest point, which is slightly above the middle of the pinnule; the apex is obtuse. Midrib visible but not prominent. The pinnule yielded a cuticle which showed quite clearly the thickened margin, sharply marked off from the under-surface by a fold that is characteristic of this genus. Unfortunately, the thin part of the lower cuticle, which would normally show the stomata, was not preserved. The thick cuticle (up to $10 \mu \mathrm{m}$ at the margin) showed only isodiametric epidermal cells with thick walls, as occur generally in this group of coriaceous pteridosperms.

Discussion: Based mainly on cuticles, Barale $(1975,1982)$ has concluded that the genera Lomatopteris Schimper 1869 and Cycadopteris Zigno 1853 are synonymous, and that therefore Cycadopteris has priority.

Ecology: From the localities at which different species of the genus are found, Barale (1982) suggested small islands as a habitat, with a strong marine influence. 


\section{Genus Pachypteris Brongniart 1828}

Pachypteris sp. cf. lanceolata Brongniart (Plate IV, 1-7)

Material studied: Coll. no.13514, 13517, 13518, 13520, 13558, 14169, 14177.

Description: The several fragments range from single pinnules (smallest $8 \times 3 \mathrm{~mm}$; largest, which is slightly lobed, $23 \times 6 \mathrm{~mm}$ ) to three fragments composed of four pinnules each. One of them is an apical fragment of a pinna, of which the largest pinnule is $9.0 \times 3.5 \mathrm{~mm}$. Another is a fragment probably slightly below a pinna-apex, as the pinnules also decrease in size the largest being $7.0 \times 3.5 \mathrm{~mm}$. The third fragment is $23 \mathrm{~mm}$ long and all four pinnules are about the same size, $9.0 \times 3.0 \mathrm{~mm}$. The pinnules are lanceolate to ovate, sometimes slightly lobed or incompletely divided (see Plate IV, 3), in the three pinna fragments arising at an angle of about $45^{\circ}$ to the rachis. The margins are entire and not thickened, the basiscopic margin decurrent. All pinnules show the midrib but it is not very prominent. No lateral veins are visible but their position in the larger pinnules is indicated on the lower cuticle.

Cuticles thick, hypostomatic; upper up to $10 \mu \mathrm{m}$ thick, showing isodiametric cell outlines with broad, straight anticlinal walls normally not interrupted by pits. Sitomata and trichomes absent. Lower cuticle (up to $8 \mu \mathrm{m}$ thick) with numerous, scattered and variably orientated stomata which tend to avoid the margins; they also avoid the midrib - and in the larger pinnules - the lateral veins. Veins indicated by elongated epidermal cells. Stomata usually but not always separated by isodiametric ordinary epidermal cells; stomatal complexes mainly monocyclic, sometimes incompletely dicyclic; subsidiary cells $4-6$. Index number of subsidiary cells/stomatal complex, following Clement-Westerhof (1984) a specific character, is 4.9-5.2. (According to this author a variability of 0.3 is normal within any one species.) Stomatal pit with a thick margin, distal walls of subsidiary cells often also thickened.

Besides our material from Lothbeg Point there are also two recently collected fragments of the same species from Culgower, one of which is quite large and shows lobed pinnules.

Discussion of generic assignment: Seward (1911) described three different species of Thinnfeldia from the Jurassic flora of Sutherland:

(1) Thinnfeldia rhomboidalis Ettingshausen, of which he had five specimens, characterised by a decurrent lower margin of the pinnule, a narrow and usually fairly deep sinus between upper portion of the pinnule base and the rachis and a distance between two adjacent pinnules normally of 1-2 $\mathrm{mm}$.

(2) Thinnfeldia arctica, with almost no space between adjacent pinnules and in which the angle between the pinnules and the rachis is normally larger (up to $90^{\circ}$ ) than in $T$. rhomboidalis $\left(30-45^{\circ}\right.$ ), leading to a much less decurrent lower pinnule margin and virtual absence of the sinus. In our opinion, $T$. rhomboidalis and T. arctica as described by Seward are the same species. 


\section{PLATE IV}
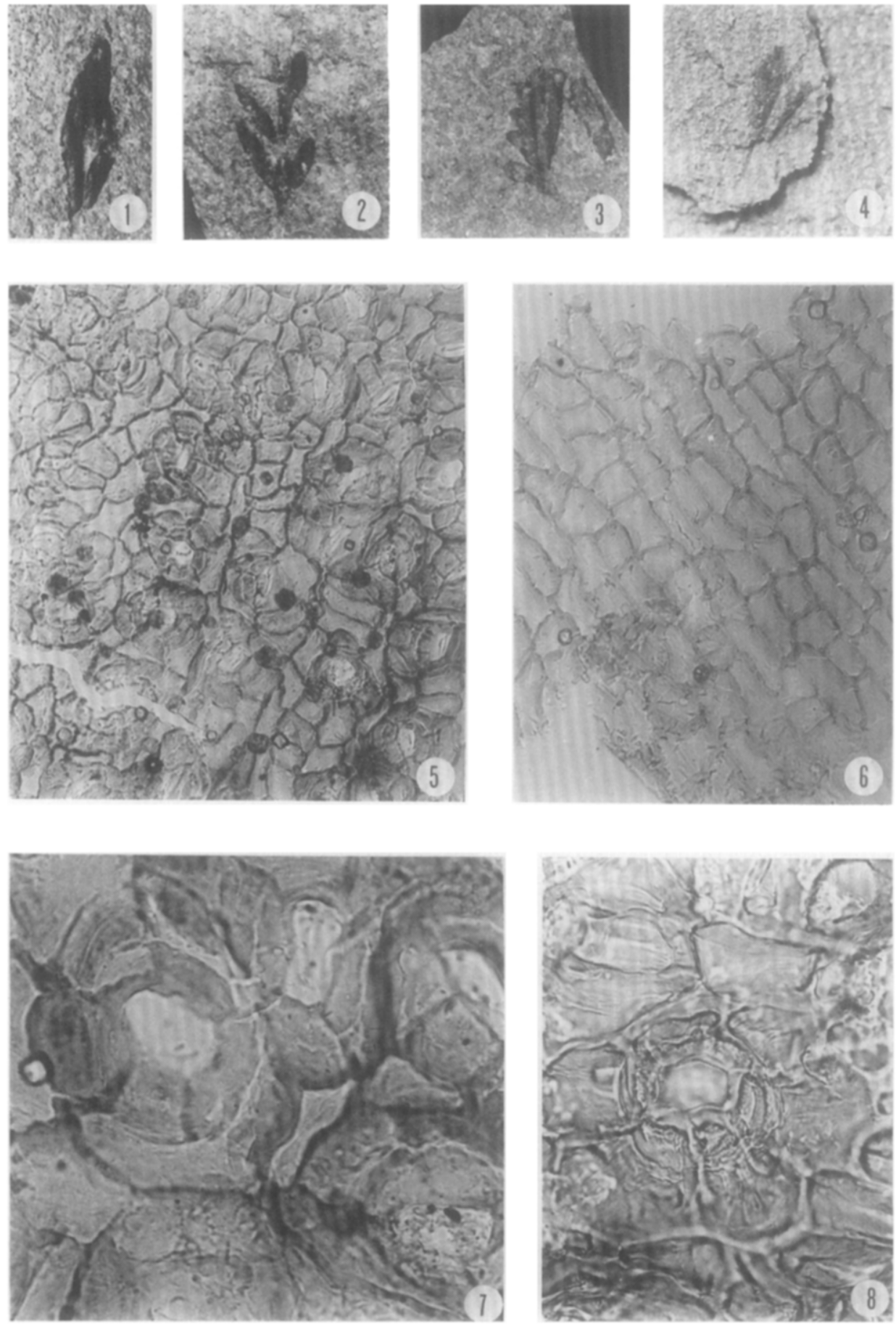
This statement is based on the similarity of their cuticles and a range of macroscopically intermediate specimens.

(3) Thinnfeldia de-geerii (Nathorst) Seward, of which he had only one pinnule with, in our opinion, too few details to be sure even of the generic assignment.

We consider that all of these specimens named Thinnfeldia from Culgower and Helmsdale should be included within Pachypteris cf. lanceolata, based on examination of their cuticles.

Harris (1964), when emending the genus Pachypteris, stated that the main difference from Thinnfeldia is that the subsidiary cells of Thinnfeldia are arranged in a neat collar whilst in Pachypteris they are not very regularly arranged and are less in number (usually about five). Another difference according to Barnard (1965) is that in Thinnfeldia the veins are usually clearly seen but in Pachypteris they are obscure. According to this, our material (and Seward's) should be assigned to Pachypteris. Some authors (e.g., Doludenko, 1974) go even further and state that there are no real differences between Thinnfeldia and Pachypteris, so Pachypteris, being the older name, has priority and therefore all Thinnfeldia species should be placed in Pachypteris. In that case our material would naturally fall in Pachypteris.

Discussion of specific assignment: It is rather difficult to make a specific assignment with cnly small fragments, but there are several species of Pachypteris with which our material is clearly not conspecific: $P$. desmomera (Saporta) Barale ( = P. macrophylla Brongniart, Dr. C.R. Hill, pers. commun.) from the Upper Jurassic of France and Middle Jurassic of England, differs in the lanceolate-linear form of its pinnules and much thicker cuticle; $P$. bedukidzei Doludenko et Svanidze 1969 from the Upper Jurassic of Georgia (U.S.S.R.) has a thickened margin and in this is more like Cycadopteris; P. papillosa (Thomas et Bose) Harris from the Jurassic of Yorkshire and $P$. major (Raciborski) Reymanówna from the Jurassic of Poland both have frequent or very frequent papillae on their lower cuticle.

Several Pachypteris species, however, are rather like our material, such as the type-species $P$. lanceolata Brongniart (see Harris, 1964), known from all over the world, which is rather variable and in which ours might be included although its pinnules are often larger than known in $P$. lanceolata. The cuticles agree quite well, the only difference is that in $P$. lanceolata the cell walls are reported not to be interrupted by pits, whilst in our material there are sometimes pits present. But this may very well be caused by bad preservation, and when studying $P$. lanceolata material from Yorkshire, we found that sometimes there are a few pits in it.

PLATE IV

1-7. Pachypteris sp. cf. lanceolata Brongniart: 1 , no.14169, $\times 1 ; 2$, no.14177B, $\times 1.5$; 3 , no.14177A, $\times 1 ; 4$, no.13518, $\times 1.5 ; 5$, no.13518, lower cuticle, $\times 200 ; 6$, no. 13518 , upper cuticle, $\times 200 ; 7$, no.13518, detail of lower cuticle, $\times 600$.

8. Thinnfeldia arctica Heer, V.4362 British Museum (Nat. Hist.), Brora, cuticle, $\times 600$. 
Other species, for example $P$. shemshakensis Barnard and $P$. incisa Saporta, only differ from $P$. lanceolata in having two pinnules on the rachis between adjacent pinnae instead of at most a single one (Barnard, 1965). As the rachis and pinna arrangement is unknown in our material, assignment on this basis is impossible. Our material is thus provisionally assigned to the widespread and well known $P$. lanceolata rather than to these more local and less well known species and which may well themselves not really be distinct.

Ecology: This plant is known from many localities in Yorkshire. Most of the material is much fragmented and consists of detached pinnules and small fragments of pinnae. It is often found in sandstone, together with driftwood and often together with other tough leaves (Harris, 1964). One or two localities with more or less intact leaves show evidence of marine influence. Harris wrote that the occurrence suggests "that it was an abundant plant somewhere inland, but that it only seldom grew in the delta itself, where it could fill the sediment with intact leaves". However, according to Vachrameev et al. (1978), it is known only from sediments deposited in the littoral zone and thus in marine environment. $P$. lanceolata may be considered a plant of rather barren circumstances including some inland places.

\section{Order GINKGOALES}

\section{Genus Ginkgo Linnaeus 1771}

cf. Ginkgo sp. (Plate V, 1, 2, VI, 7)

Material studied: Coll. no.14171.

Description: The single specimen is a wedge-shaped leaf impression. There is only a little fossil material preserved at its edges but this yielded a good cuticle. The impression ( $45 \mathrm{~mm}$ long) shows a petiole, $6.0 \mathrm{~mm}$ wide, which widens into an undivided wedge-shaped leaf up to $30 \mathrm{~mm}$ wide. The apex is unknown and the veins are not visible.

Cuticles thick, upper about $5 \mu \mathrm{m}$ thick, lower about $4 \mu \mathrm{m}$. Upper cuticle with isodiametric polygonal cells and occasional scattered stomata. Veins indicated by slightly elongated cells. Lower cuticle with narrow vein strips, marked by longitudinal rows of elongated more or less rectangular cells. Strips between veins with isodiametric polygonal cells, not arranged in rows. Stomata scattered between the veins or forming short rows of about three stomata, irregularly orientated but with a tendency towards longitudinal. Guard cells slightly sunken. Surface thickening of subsidiary cells variable, usually forming a rim around the pit. Occasional subsidiary cells with a solid

PLATE V

1, 2. cf. Ginkgo sp.: 1 , no. $14171, \times 1 ; 2$, no.14171, lower cuticle, $\times 200$.

$3-5$. Czekanowskia sp. cf. rigida Heer: 3 , no.13510B, $\times 1 ; 4$, no.13523, cuticle, $\times 200$; 5 , no.13523, detail of cuticle, $\times 600$. 


\section{PLATE V}
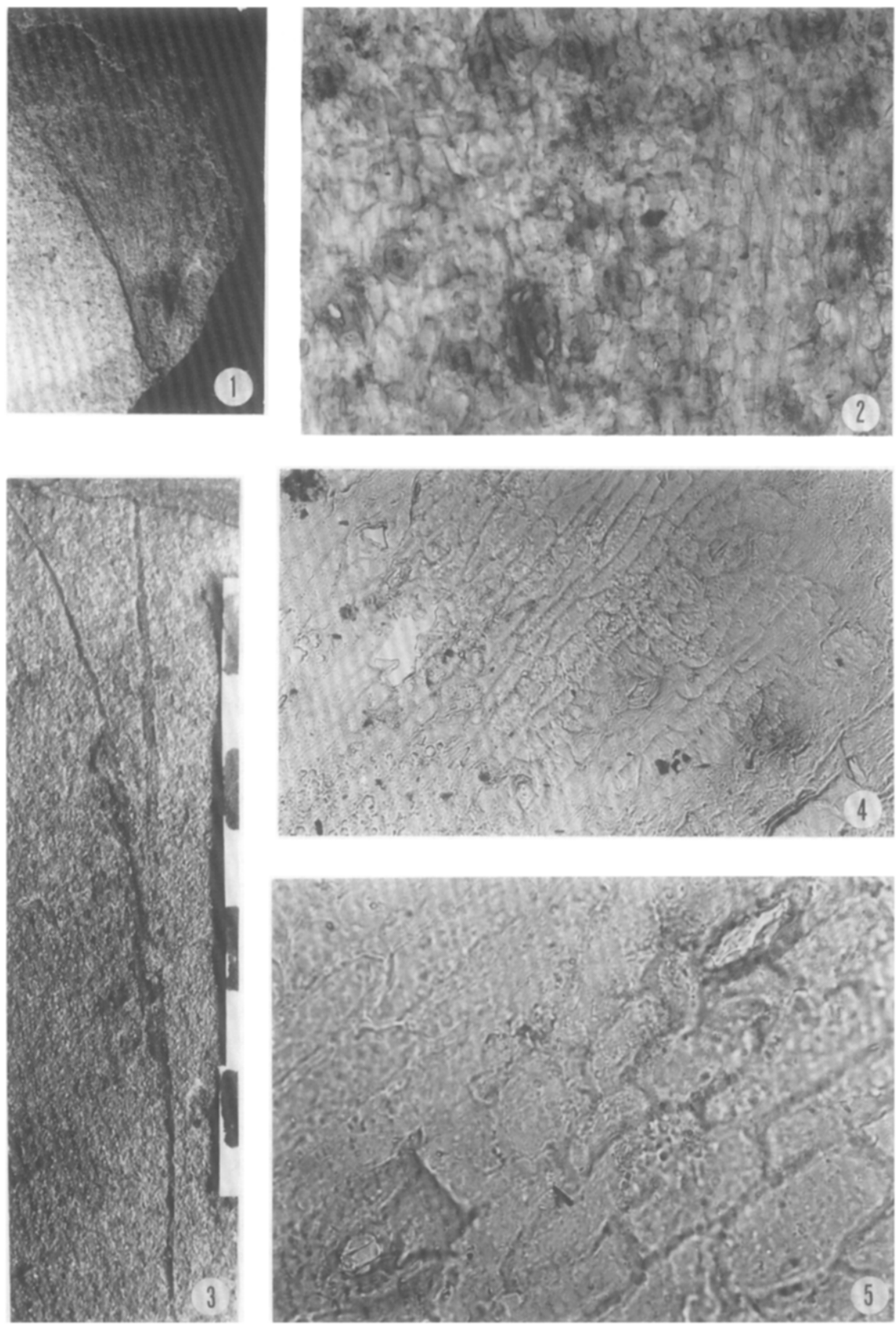
papilla projecting towards the pit. Number of subsidiary cells $4-6$. Encircling cells absent.

Discussion: This leaf fragment is provisionally assigned to Ginkgo on the basis of its leaf form. The cuticle, however, resembles a Sphenobaiera cuticle more than a Ginkgo one, although there is great variability within Ginkgo. The cuticle did not match any Ginkgoalean cuticle known to us. Although it shows some similarity to that of Sphenobaiera gyron Harris et Millington from the Jurassic of Yorkshire, the thickening of the subsidiary cells is much less marked in our material and encircling cells are not present.

Stopes (1907) described Ginkgo digitata (Brongniart) Heer from Brora, including a cuticle fragment with some stomata. These show some resemblance to our material but there are too few data to make any real comparison. From Ginkgo digitata var. huttonii, described by Seward and Bancroft (1913) no cuticle has been described.

Ecology: The ecology of this plant is unknown.

\section{Order CZEKANOWSKIALES}

\section{Genus Czekanowskia Heer 1976}

Czekanowskia sp. cf. rigida Heer (Plate V, 3-5)

Material studied: Coll. no.13197, 13198, 13510, 13513, 13523, 13524, 14176.

Description: Our material consists of several small fragments of foliage leaves (the smallest being $10.0 \mathrm{~mm}$ long and $1.5 \mathrm{~mm}$ wide) and one large, onceforked fragment $110 \mathrm{~mm}$ long and $1.0-1.5 \mathrm{~mm}$ wide. The short shoot is unknown. Neither the base nor the apex is shown in the large leaf fragment but in the upper region the taper of the leaf segments suggests the approach of the apex. The angle of forking is $15^{\circ}$ and the fork is at $45 \mathrm{~mm}$ from the base of the fragment, leaving two leaf segments of $65 \mathrm{~mm}$ length. All fragments yielded good amphistomatic cuticles, about $4 \mu \mathrm{m}$ thick. Stomata forming 3--8 longitudinal files on each surface, but some files irregular and some stomata out of file. Files rather unevenly spaced. Epidermal cells between stomatal files elongated, several times as long as broad, forming short longitudinal files. Cells between successive stomata of stomatal files shorter, sometimes even square. Number of epidermal cells between stomata in a stomatal file rather variable $(1-8)$, stomata never in contact. Stomata always longitudinally orientated, subsidiary cell group (4-6 subsidiary cells) varying from slightly elongated to isodiametric. Surface of subsidiary cells normally slightly thicker than that of ordinary cells. Stomatal pit normally wide, but sometimes narrow. Border of pit not very conspicuous, hardly ever forming papilla-like ingrowth. Trichomes absent (but the leaf base, where they frequently occur in Czekanowskia, is unknown).

Discussion: Seward (1911) mentioned one imperfectly preserved specimen of Czekanowskia murrayana Lindley et Hutton, now named Solenites vimineus 
(Phillips) Harris, which he considered to be identical with Czekanowskia rigida Heer. Harris and Rest (1966) mentioned undeterminable Czekanowskia fragments from the Jurassic of Brora, but did not give any description or figure.

Many authors (e.g. Doludenko and Rasskazova, 1972; Doludenko and Orlovskaya, 1976), believe $C$. rigida to be conspecific with $C$. setacea Heer, as the only difference is in the width of the leaf segments and the cuticles of both species agree very well with each other. C. rigida normally has onceforked leaves though twice-forked leaves are not exceptional. Thus our once-forked leaf fragment may be placed in C. rigida, especially as the cuticles are rather alike (in $C$. rigida the subsidiary cell surface is normally strongly and evenly thickened, but sometimes only slightly thicker cells also occur, as in our specimens). The specimens do not agree completely with the common type of $C$. rigida leaves, but they fall within the range of this widespread species. There are several other, once-forked Czekanowskia species, such as $C$. ketovae Orlovskaya from the Jurassic flora of the Karatau which has much broader leaf segments (up to $3 \mathrm{~mm}$ ) and in which the stomata within the files are much closer placed. This species may belong to the genus Sphenarion Harris et Miller 1974, just as they considered for Czekanowskia latifolia Turutanova Ketova. C. auliensis Doludenko from the Jurassic of the Karatau has long (up to $30 \mathrm{~cm}$ ) once-forked, $1.0-1.5 \mathrm{~mm}$ wide leaves. The angle of forking is greater than in C. rigida (up to $30^{\circ}$ ) and the stomata are very prominent because of their heavily thickened subsidiary cells. $C$. aciculata Krassilov (1972) from the Mesozoic flora of the Bureja basin has short (up to $10 \mathrm{~cm}$ ) once-forked leaves with also very prominent stomata. The angle of forking is normally $45^{\circ}$. C. furcula Harris et Miller from the Jurassic of Yorkshire is in general habit rather like our specimens, but the stomata are again prominent and the border of the stomatal pit is usually broad and conspicuous which is not the case in our material. Also C. thomasii Harris et Miller from the Yorkshire Jurassic has once-forked leaves, but here the leaf segments are normally only $0.5 \mathrm{~mm}$ wide and the leaves are much shorter than in our material (maximum length $8 \mathrm{~cm}$ ).

Ecology: Based on the occurrence of Czekanowskia generally in localities reflecting moist lush vegetation, deposited under quiet circumstances, it is supposed to be a plant growing in such vegetation.

\section{Genus Phoenicopsis Heer 1876}

Phoenicopsis gunnii Seward emend. (Plate VI, 1-5)

Material studied: Coll. no.13512A, C, 14165, 14166, 14167.

Description: In our material from Lothbeg Point there are five fragments of this species. Phoenicopsis gunnii is known only from the Upper Jurassic of Scotland and was first described by Seward in 1911, based on a single specimen from Culgower consisting of fragments of seven leaves converging to a common base (his plate X fig.35). He did not describe its cuticle. Dr. C.R. Hill 
(British Museum, Natural History) provided a fragment of Seward's specimen from which the cuticle was prepared (V.12205). This cuticle agreed perfectly with the cuticle prepared from the Lothbeg Point specimens. Our assignment of the Lothbeg Point material to P. gunnii was made on this basis, and the description of $P$. gunnii is here emended because of the addition of the cuticle data.

Emended description: Leaves converging to a common base, tapering towards the apex, no basal bracts known, apex rounded, lamina $2-4 \mathrm{~mm}$ wide, maximum length known $120 \mathrm{~mm}$. Number of veins varying from 3 in a $2 \mathrm{~mm}$ wide leaf to about 8 in a $4 \mathrm{~mm}$ wide leaf, possibly in addition to traces of interstitial veins or fibrous strands. Cuticle fairly thick $(4-5 \mu \mathrm{m})$, amphistomatic. Stomata placed in 6-10 longitudinal files on each surface, sometimes occurring out of file. Files rather unevenly spaced, not forming compound stomatal bands. Epidermal cells between stomatal files elongated, forming longitudinal files, cells between successive stomata within the stomatal files shorter, sometimes almost square. Stomata always longitudinally orientated. Subsidiary cell group slightly elongated with two terminal and 2-4 lateral subsidiary cells. Stomatal pit normally wide (round or oval). Rim of subsidiary cells often projecting over pit as separate papillae. Encircling cells absent.

Discussion: Our material consists of five specimens, two consisting of fragments of two parallel leaves. In one of these the two leaf fragments are each $20 \mathrm{~mm}$ long and 2.0 and $2.5 \mathrm{~mm}$ wide respectively, converging slightly to a common base. The narrowest fragment contains three veins, the other four. The other specimen is still smaller: two parallel-running leaf fragments, 12 and $10 \mathrm{~mm}$ long, both $2.0 \mathrm{~mm}$ wide and each containing three veins. Two other specimens consist only of one leaf fragment $(26 \times 2.0 \mathrm{~mm}$ and $15 \times$ $2.5 \mathrm{~mm}$ ) and one specimen consists of a $66 \mathrm{~mm}$ long, 1.5-2.5 mm wide leaf fragment with parallel to it a $10 \mathrm{~mm}$ long and $2.0 \mathrm{~mm}$ wide leaf fragment. On the same block there is a third fragment $22 \mathrm{~mm}$ long and $2.0 \mathrm{~mm}$ wide, orientated perpendicular to the other two.

Seward (1911) stated that the species nearest to $P$. gunnii is $P$. angustifolia Heer, recorded from the Jurassic of Siberia and China, differing mainly in the narrower leaves (in $P$. angustifolia $4-5 \mathrm{~mm}$ wide) and the absence of interstitial veins. Nowadays more such species are known (all from Siberia, China or Franz-Josephland), but they differ in their length, width or number of veins.

Samylina (1971) in her monograph on Phoenicopsis compared all known species with one another and divided them into three sections based mainly on cuticle characters: Phoenicopsis, Culgoweria (in which she included

\section{PLATE VI}

1-5. Phoenicopsis gunnii Seward: 1 , no.13512C, $\times 1 ; 2$, no.13513A, $\times 1 ; 3$, no.14165, $\times 1 ; 4$, no.13512, cuticle, $\times 200 ; 5$, no.13512, stoma, $\times 600$.

6. Elatides curvifolia (Dunker) Nathorst, no.14170, $\times 1$.

7. cf. Ginkgo sp., no.14171, detail of cuticle, $\times 600$. 


\section{PLATE VI}
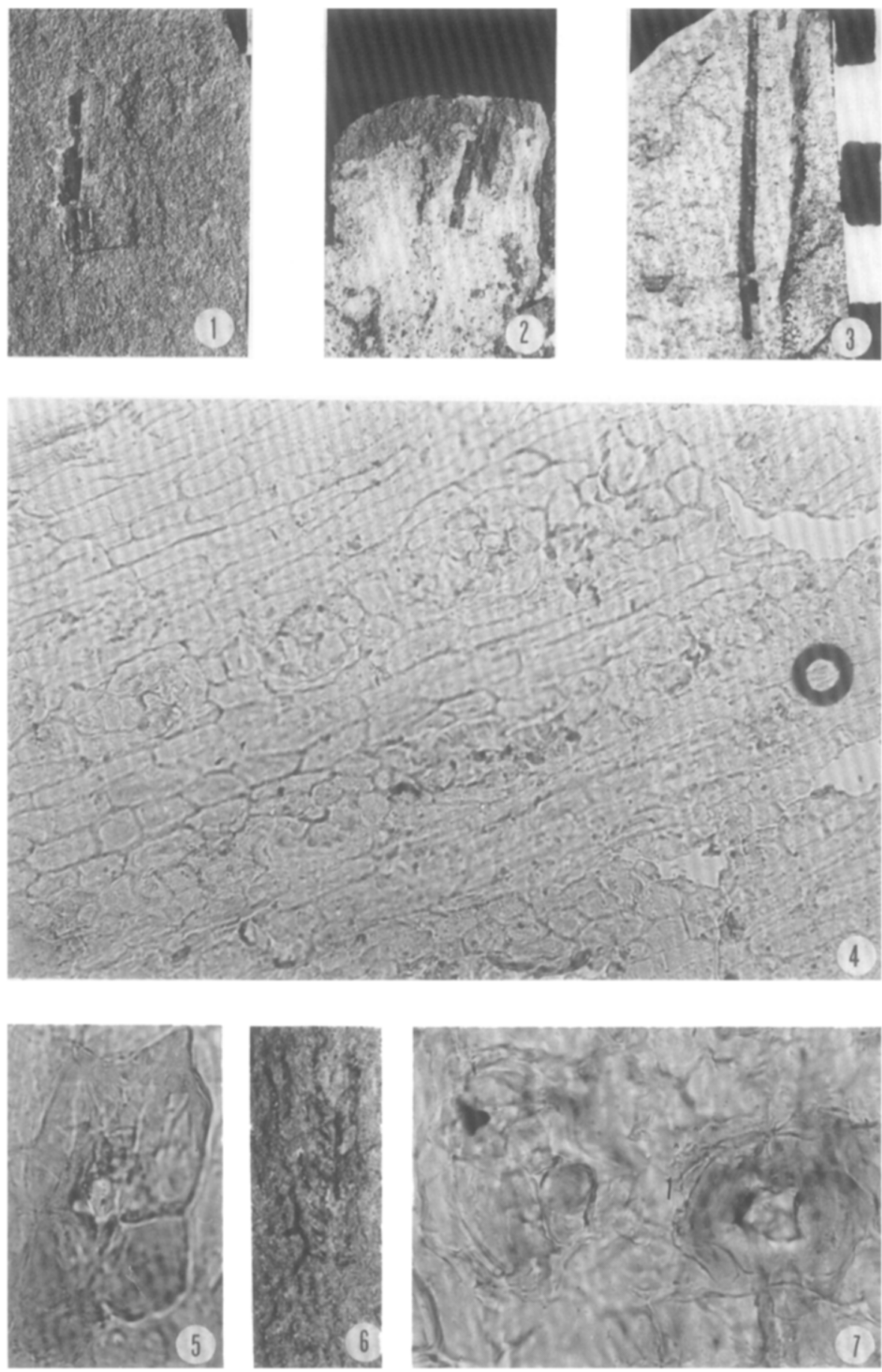
$P$. gunnii) and Windwardia. Section Phoenicopsis is hypostomatic, Culgoweria and Windwardia are both amphistomatic. In section Culgoweria the stomata are in files unevenly placed over the whole surface but never arranged in bands, as is the case in Windwardia. She apparently studied the cuticle of $P$. gunnii but did not describe it and only used it for comparison with new species within section Culgoweria. P. gunnii, according to her, seems to be nearest to $P$. vassilevskiana Samylina, differing mainly in the length of the leaves (only $30-50 \mathrm{~mm}$ in $P$. vassilevskiana) and in the absence of papillae from the subsidiary cells.

Ecology: The Jurassic beds in Sutherland are the only occurrence of the genus in Western Europe. Outside this area it is found frequently together with Czekanowskia, especially in Siberia, reflecting the same type of vegetation. Based on the Siberian finds there seems to be a preference for somewhat drier habitats. Therefore, it is considered to be a plant of upland forest.

Order CONIFERALES

Family TAXODIACEAE

\section{Genus Elatides Heer 1876}

Elatides curvifolia (Dunker) Nathorst (Plate VI, 6)

Material studied: Coll. no.14170, 14174.

Description: Our material consists of two badly preserved specimens. One is an unbranched shoot $60 \mathrm{~mm}$ long and $8 \mathrm{~mm}$ wide, the other an unbranched shoot $110 \mathrm{~mm}$ long and $8-9 \mathrm{~mm}$ wide. In both specimens the falcate leaves are spirally arranged and their free part measures $5-6 \mathrm{~mm}$ by about $1 \mathrm{~mm}$. The leaf base cushion on the stem is about $1-2 \mathrm{~mm}$ long. The leaves yielded only tiny bits of a delicate cuticle $(1 \mu \mathrm{m}$ thick) showing polygonal epidermal cells but none showing stomata.

Discussion: This characteristically Wealden species is represented in the Lothbeg Point flora by only two specimens but is one of the most common species at Culgower (Seward, 1911). It has also been described from the Lower Cretaceous of Spitsbergen (Nathorst, 1897). Seward described male and female cones from the Jurassic of Scotland which he attributed to $E$. curvifolia, but the female cone and the cone scales in his text-fig.10 show a single median seed on the cone scales, suggesting an araucarian rather than a taxodiaceous affinity. These cones and scales, therefore, may belong to another species. We have collected fresh material from Culgower, to be described in a later paper, in which there are found a great many $E$. curvifolia shoots and also female cones that look more like the female cones of species such as E. williamsonii and E. thomasii (Harris, 1979). Provisionally we refer the shoots found both at Culgower and at Lothbeg Point to $E$. curvifolia as they show a great deal of resemblance to this species.

Seward (1911) also described E. sternbergiana (Schenk) Seward from the Jurassic of Scotland, stating that this specimen closely resembles $E$. curvifolia 
but differs in its shorter $(3-4 \mathrm{~mm})$ and rather more crowded leaves. We believe that this specimen may very well be placed in $E$. curvifolia though the possibility of its belonging to another species or even genus should not be excluded.

Ecology: This conifer is known typically from the Wealden deposits of Western Europe, a facies of wet lowlands with repeated marine transgressions and episodes of peat formation. The Yorkshire species of the genus, though different, also preferred moist circumstances and are found in deposits of lush vegetation. Therefore, $E$. curvifolia is considered to be a plant of lowland forest.

\section{Genus Taxodiophyllum gen. nov.}

Description: (Shoots unknown.) Leaves simple, flat, linear, single veined. Basal and distal ends of leaves gradually tapering. Cuticles thick, hypostomatic. Upper epidermis consisting of almost uniform polygonal cells. Lower cuticle divided into more than one stomatal band on each side of the vein, separated by bands of rectangular outlines of ordinary epidermal cells, corresponding with subepidermal strands of probably sclerenchymatous (?fibrous) tissue. Within a stomatal band, stomata longitudinally orientated, forming files separated by ordinary cells. Guard cells slightly sunken in stomatal pit. Subsidiary cell-group elongated, terminal subsidiary cells covering guard cell poles. Midrib indicated by a broad non-stomatal band; also broad marginal zones without stomata.

Type species: Taxodiophyllum scoticum nov. sp.

Name: Suggesting possible affinity with the Taxodiaceae, discussed below.

Diagnosis: This genus is established for linear coniferous leaves which have only one vein as in Pityophyllum Nathorst 1897, but which normally show more than one stomatal band on each side of the vein.

Discussion: This genus is based on over seventy leaves and fragments found mainly at Lothbeg Point and Krakaig Links, with some from Culgower. The cuticle is uniformly tough, thick and easy to prepare, making comparison between the various leaves possible. Of all these leaves only two narrow ones showed one stomatal band on each side of the midrib, all the others having two or more. The stomatal bands are variable in width and number of stomatal files within them, and are separated by narrow bands of elongated, normal epidermal cells, corresponding with strands of homogeneous, sclerenchymatous or fibrous tissue. The midrib is indicated by a broader nonstomatal band as is also the case with the margins.

Taxodiophyllum scoticum nov. sp. (Plate VII, 1-7, VIII, 1-4, IX, 5) (Fig.7)

Material studied: Coll. no.13456-13460, 13508, 13509, 13511, 13512, $13515,13521,13523-13549,13552,13553,13556,13557,13560,13562$, $13563,13565,14153-14155,14161,14163,14168,14175$.

Description: (Shoots unknown.) Leaves simple, flat, linear, single-veined; 
usually slightly curved, probably about $70-100 \mathrm{~mm}$ long; longest leaf fragment $86 \mathrm{~mm}$ long. Width rather variable, $2-6 \mathrm{~mm}$. Distal region of leaves gradually tapering to acute apex; basal end gradually tapering to about onethird of full width. Leaf surface glossy, sometimes showing hairs, midrib normally invisible, but when visible rather broad (up to $1.5 \mathrm{~mm}$ ). Lamina transversed longitudinally by $2-8$ sclerenchymatous strands, often showing on the surface (sometimes bearing superficial likeness to veins). Leaf margins entire. Cuticles very coherent, typically $5-10 \mu \mathrm{m}$ thick but less in stomatal bands and more in margin regions. Mesophyll and strands often preserved. Cell outlines of upper cuticle nearly uniform, mainly rectangular, length normally 2-5 times their width, forming files. Course of midrib not indicated, no papillae or trichomes present. Lower cuticle with two or more stomatal bands separated by a broad midrib region, narrower "strand" regions and broad marginal regions (Fig.7). In all these regions epidermal cells like those of upper cuticle. Stomatal bands rather variable in width, narrowing towards le af base, narrowing and converging towards apex, often joining together. Stomatal bands comprising 3-12 stomatal files, sometimes also scattered stomata out of file. Stomata longitudinally orientated, often in contact but never sharing subsidiary cells. Guard cells slightly sunken in stomatal pit. Subsidiary cell group elongated, consisting of two terminal subsidiary cells, covering guard cell poles, and 2-4 lateral subsidiary cells. Subsidiary cells often more heavily cutinized than ordinary epidermal cells, very rarely showing papillae. No encircling cells present. Ordinary epidermal cells within stomatal band polygonal, often square. No trichomes present, but sometimes long hairs.

Name: After Scotland where this material was found.

Holotype: Coll. no.13508, Laboratory of Palaeobotany and Palynology, Utrecht.

Discussion: Taxodiophyllum scoticum is one of the commonest fossils at Lothbeg Point. The type specimen is a whole leaf $83 \mathrm{~mm}$ long with a greatest width of $5 \mathrm{~mm}$. Another complete leaf (13521) is $48 \mathrm{~mm}$ long, greatest width $4 \mathrm{~mm}$. Both are curved and the larger leaf fragments are also normally curved. The longest leaf fragment is $86 \mathrm{~mm}$ long. The width found in the leaf fragments varies between 2 and $6 \mathrm{~mm}$, but most are 3-4 $\mathrm{mm}$ wide. In some leaves the substance is so thick that no midrib or strands are visible, but normally the strands are visible (looking like veins, but macerations show that they are sclerenchymatous strands), and sometimes the broad midrib is also visible. Midrib and strands are always indicated in the lower cuticle. Some specimens yielded a coarser, more heavily cutinized cuticle (13528,

\section{PLATE VII}

1-7. Taxodiophyllum scoticum sp. nov.: 1 , no.13508B, type specimen, $\times 1 ; 2$, no.14175, large leaf, $\times 1.5 ; 3$, no.13461, small leaf, $\times 1 ; 4$, no.14153, $\times 1 ; 5$, no.14168, showing midrib, $\times 1 ; 6$, no.13528, abnormal cuticle, $\times 200 ; 7$, no.13508B, upper cuticle from type specimen, $\times 200$. 


\section{PLATE VII}
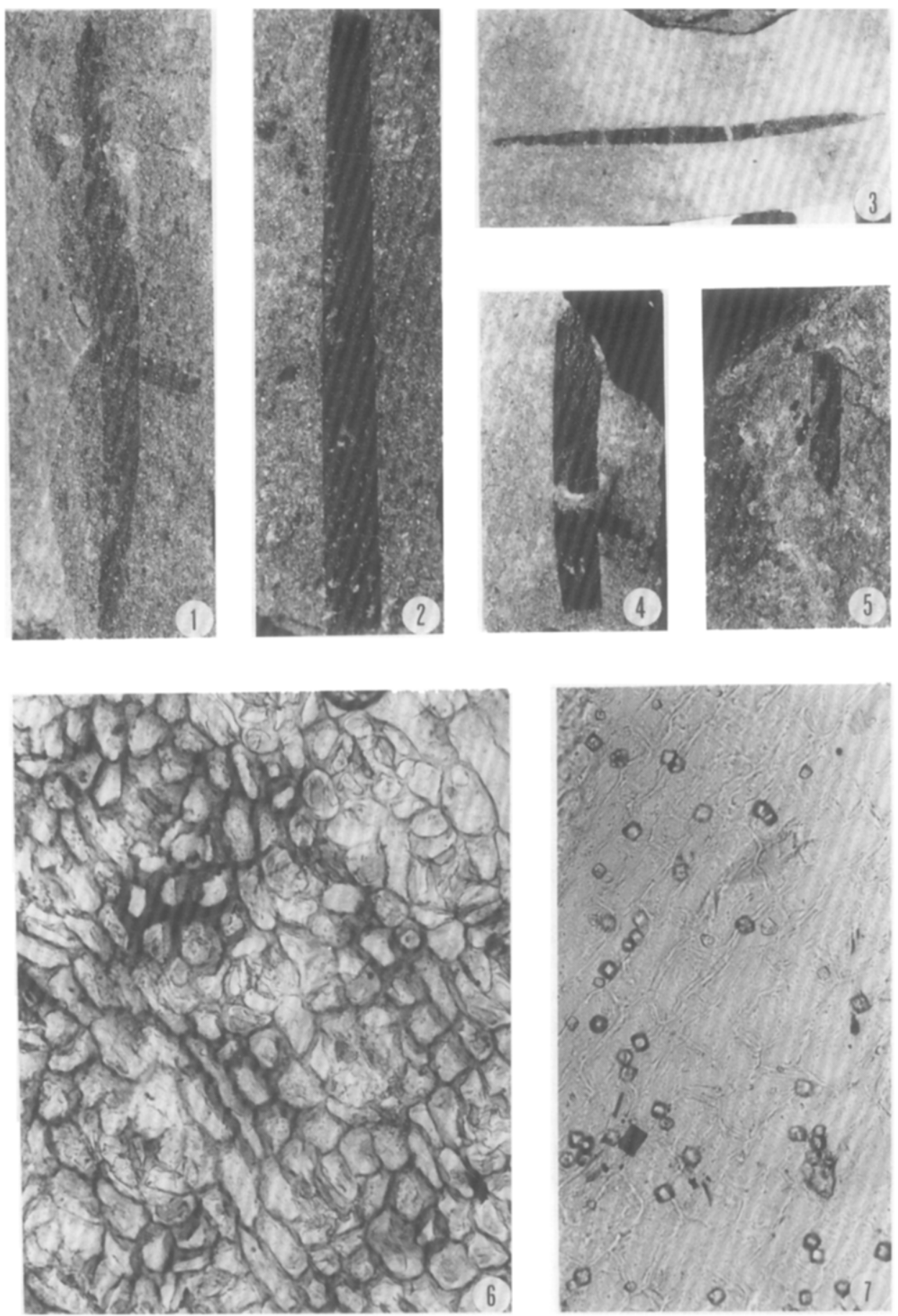


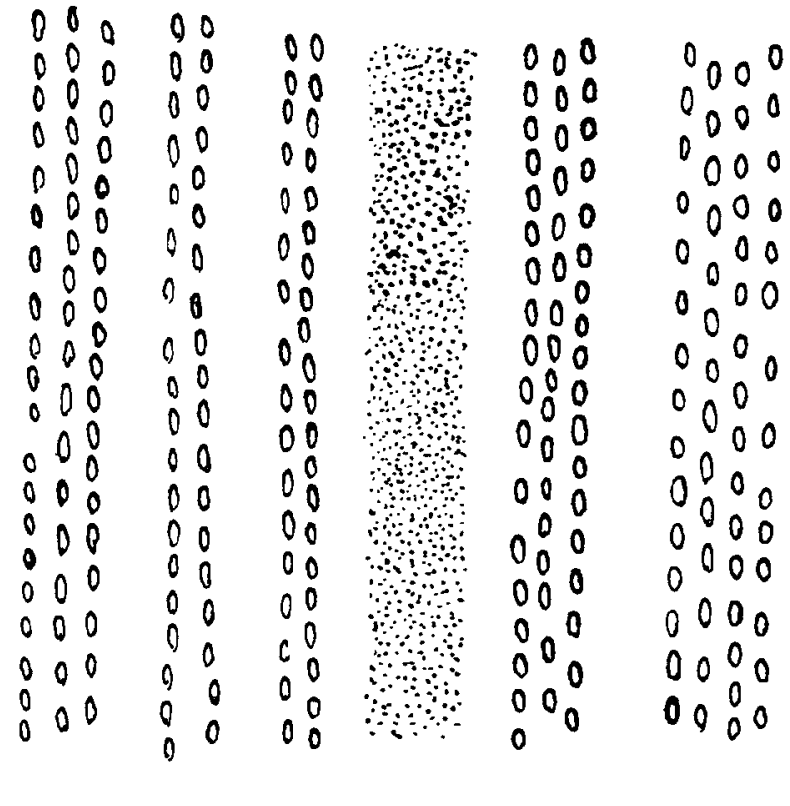

Fig.7. Taxodiophyllum scoticum nov. sp., scheme of the position of the midrib and of the stomatal bands.

13553), but otherwise the cuticle shows the same features as the ordinary material. The reason for this coarseness is unknown. This species is distinguished from a variety of macroscopically similar species by the occurrence of more than one stomatal band on each side of the midrib. Most of the species that are rather like it fall within the genus Pityophyllum in which also some markedly similar species occur (Tralau, 1966; Harris, 1979), though they are normally narrower than in our species and never have more than two stomatal bands.

Storgaardia Harris (1935) also has some similar features, but both the apex and the base taper over a much shorter distance than in our species, the cuticle is thin and has only two stomatal bands. The stomata also differ in having a thickly cutinized rim of subsidiary cells with papillae.

Another species that shows some agreement is Bilsdalea dura Harris from the Jurassic of Yorkshire. Although its leaves are normally much shorter, long curved leaves up to $80 \mathrm{~mm}$ occur, but again there is only one stomatal band on each side of the midrib. The stomata themselves are rather similar (Harris, 1979). The ginkgoalean Pseudotorellia Florin (1936) shows close

PLATE VIII

1-4. Taxodiophyllum scoticum sp. nov.: 1 , no.13529, lower cuticle, $\times 200 ; 2$, no.13508B, stoma with papillae, $\times 600 ; 3$, no.13532A, closed stoma, $\times 600 ; 4$, no. $13538 \mathrm{D}$, lower cuticle showing two stomatal bands and one non-stomatal band, $\times 200$. 


\section{PLATE VIII}
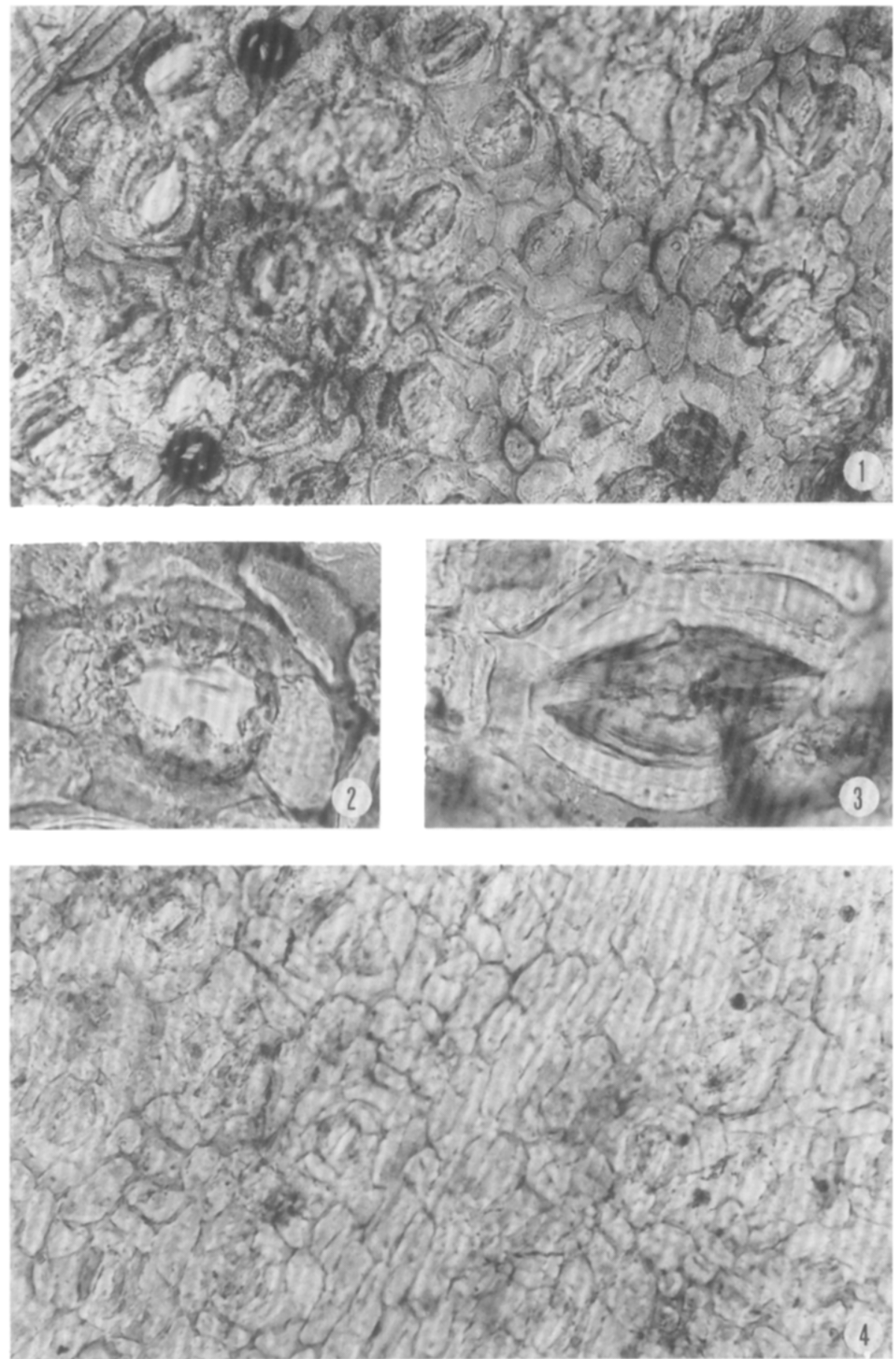
agreement. This genus has narrow, tongue-shaped, falcately curved leaves, with several veins formed by dichotomies in the basal part. The leaves are hypostomatic and the stomata are arranged in bands between the veins. The cuticle in particular is very much like that of Taxodiophyllum scoticum, the main difference is of course the presence of several veins in Pseudotorellia whilst there is only one vein in Taxodiophyllum scoticum. When studying our material, we first thought that we had a Pseudotorellia species because the sclerenchymatous strands often show on the outside just like veins. Several specimens (such as the type-specimen), however, showed some of the interior material and it appeared they were only sclerenchymatous strands and not veins. Our material shows just one broad midrib (see Plate VII, 5). Also the veins in true Pseudotorellia species end separately, as in all ginkgoalean species, at or just below the apical margin, whilst in our species the strands converge, as do the stomatal bands, towards the apex (a feature of the Coniferales). It might be possible that some Pseudotorellia species, especially the long, narrow ones of which the apex is not known, may be of coniferalean instead of ginkgoalean affinity, and may belong to Taxodiophyllum or a similar genus.

Seward (1911) described under the name Taxites sp. cf. T. gramineus (Heer) Nathorst some fragments of leaves from Culgower that show some agreement with our material. They are up to $4.5 \mathrm{~mm}$ wide and the longest fragment is $40 \mathrm{~mm}$ long. There is a distinct midrib. No cuticle is known and after studying these fragments we believe that no cuticle will ever be known. But macroscopically they resemble our material. Seward prefers to use the generic name Taxites instead of Pityophyllum for coniferous leaves of the form met in Taxus, Cephalotaxus, Torreya, etc. Next to Pityophyllum and Taxites species with which he compared those leaves, he also compared them with Abietites linkii (Römer) Dunker. We have also studied material of this European Wealden species and found that it was very like our material. It is the only other fossil coniferalean species known to us that has a midrib and more than two stomatal bands (normally 3 or 4 , sometimes even 6 ). The whole organisation and appearance of the cuticle is rather similar although there are some differences such as the highly cutinized subsidiary cells with papillae (Plate IX, 1). Also the stomatal bands are not so well separated from the non-stomatal bands as in our material, and the normal epidermal cells are less elongated (normally only $2-3$ times as long as broad).

Comparison with recent conifers: We have studied cuticle material of conifers from various families. Although hypostomatic cuticles with a smaller or

\section{PLATE IX}

1. Abietites linkii (Römer) Dunker, Otavi Werke, Wealden, lower cuticle, $\times 200$.

2. ? Female cone scale, no.13516, $\times 2$.

3, 4. Sequoiadendron giganteum (Sinal) Bucholz.

3 . Slide no.462, stoma, $\times 600$.

4. Slide no.462, cuticle, $\times 200$.

5. Taxodiophyllum scoticum sp. nov., no.13549B, lower cuticle, $\times 200$. 


\section{PLATE IX}
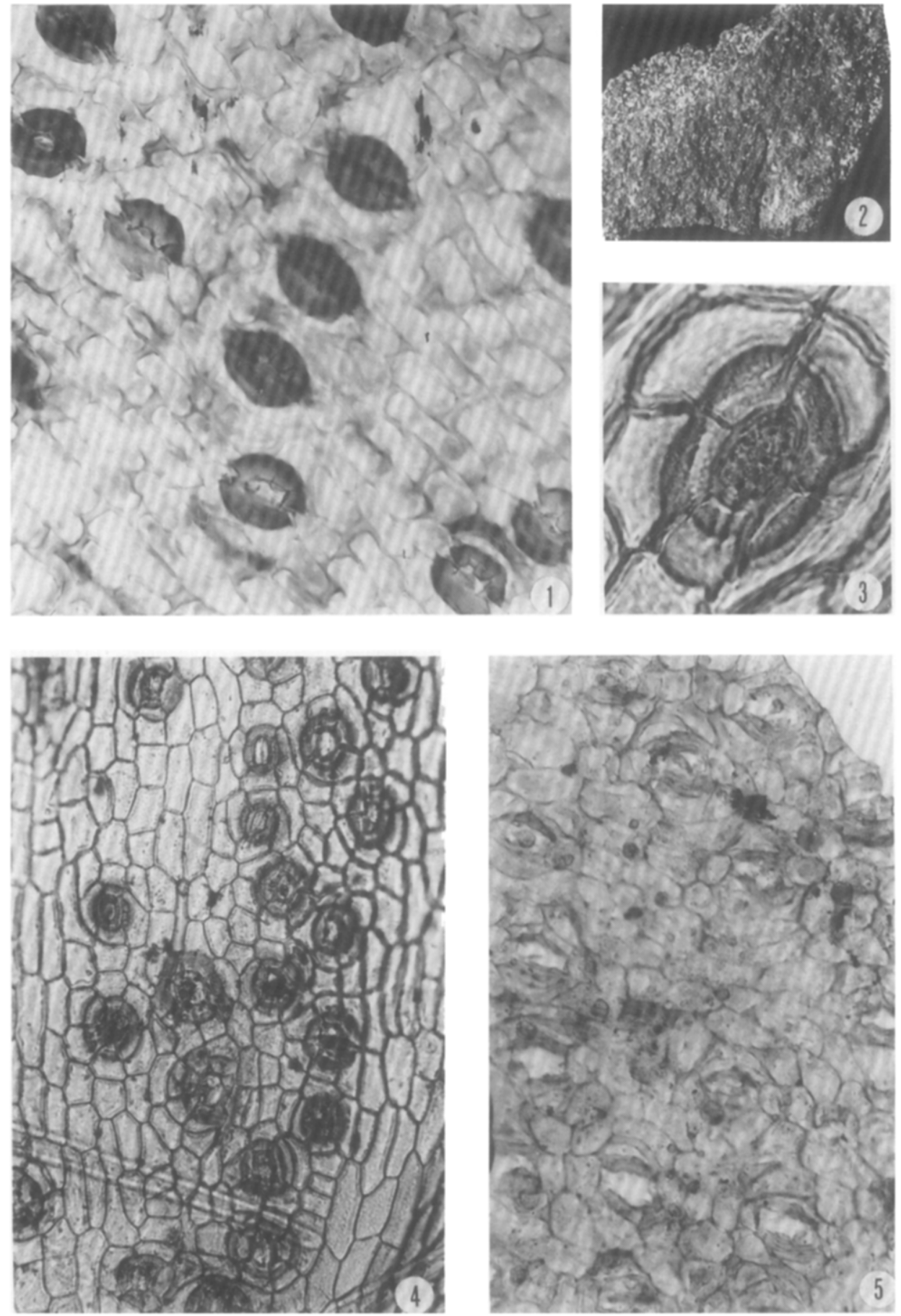
broader stomatal band on each side of the midrib are common in most families, there is only one in which we found hypostomatic cuticles with more than one stomatal band on each side of the midrib: Taxodiaceae. Of this family we studied seven species in six genera. Cunninghamia lanceolata Hooker has the normal coniferous type of cuticle with one stomatal band on each side of the midrib. Taxodium distichum Richards and T. ascendens Brongniart often have only one stomatal band on each side of the midrib but they show a tendency to divide in the middle part of the leaf into more bands, joining again towards the apex. The stomata are often obliquely or transversely orientated instead of longitudinally as is the case in the other species we have examined and in the fossil material. In all of the other species, Cryptomeria japonica D. Don (Plate X, 2), Glyptostrobus lineatus Druce, Sequoiadendron giganteum (Sinal) Bucholz (Plate IX, 3,4) and Sequoia sempervirens (D. Don) Endlicher (Plate X, 1), we found often more than one, narrow or wide stomatal band on each side of the midrib, converging and joining together towards the apex. In all these species the stomata are longitudinally orientated, are arranged in files within the stomatal bands and are in general appearance like those of Taxodiophyllum scoticum (and also like Abietites linkii). This similarity in cuticle organisation between several species of the Taxodiaceae and our fossil material from the Jurassic of Scotland is the basis for naming this new genus Taxodiophyllum.

Ecology: This conifer appears to be related to Abietites linkii from the Wealden of Western Europe. In these deposits the latter is fairly abundant in clays and in coal deposits, suggesting a preference for marshy circumstances. Therefore, Taxodiophyllum scoticum is also suggested to be a plant of marshy habitats.

\section{INCERTAE SEDIS}

\section{? Female cone scale (Plate IX, 2)}

Material studied: Coll. no.13516.

Description: One specimen shows a presumably female cone scale on a stalk. The stalk is almost $2 \mathrm{~mm}$ wide and also $2 \mathrm{~mm}$ long but broken at its base. It widens into a scale consisting of a median lobe, $6 \mathrm{~mm}$ long and almost $3 \mathrm{~mm}$ wide, and two smaller marginal lobes, one of which is broken, the other being $4 \mathrm{~mm}$ long and $1.5 \mathrm{~mm}$ wide. The apex of all the lobes is rounded. There is no sign of a seed or a place of attachment. The substance is thick and we tried to prepare a cuticle from the stalk. The cuticle is thick $(5 \mu \mathrm{m})$ but it broke into small fragments, which only showed rectangular epidermal cells, mainly $2^{--3}$ times as long as broad.

Discussion: on the assumption that this female scale may belong to a plant fossil known from the Lothbeg Point flora, the thickness of the cuticle indicates that it may belong either to a pteridosperm (Pachypteris cf. lanceolata or Cycadopteris sp.) or to Taxodiophyllum scoticum. The rectangular elongated epidermal cells point more in the direction of $T$. scoticum than of a pteridosperm, but nothing definite can be said until more is known. 


\section{PLATE X}
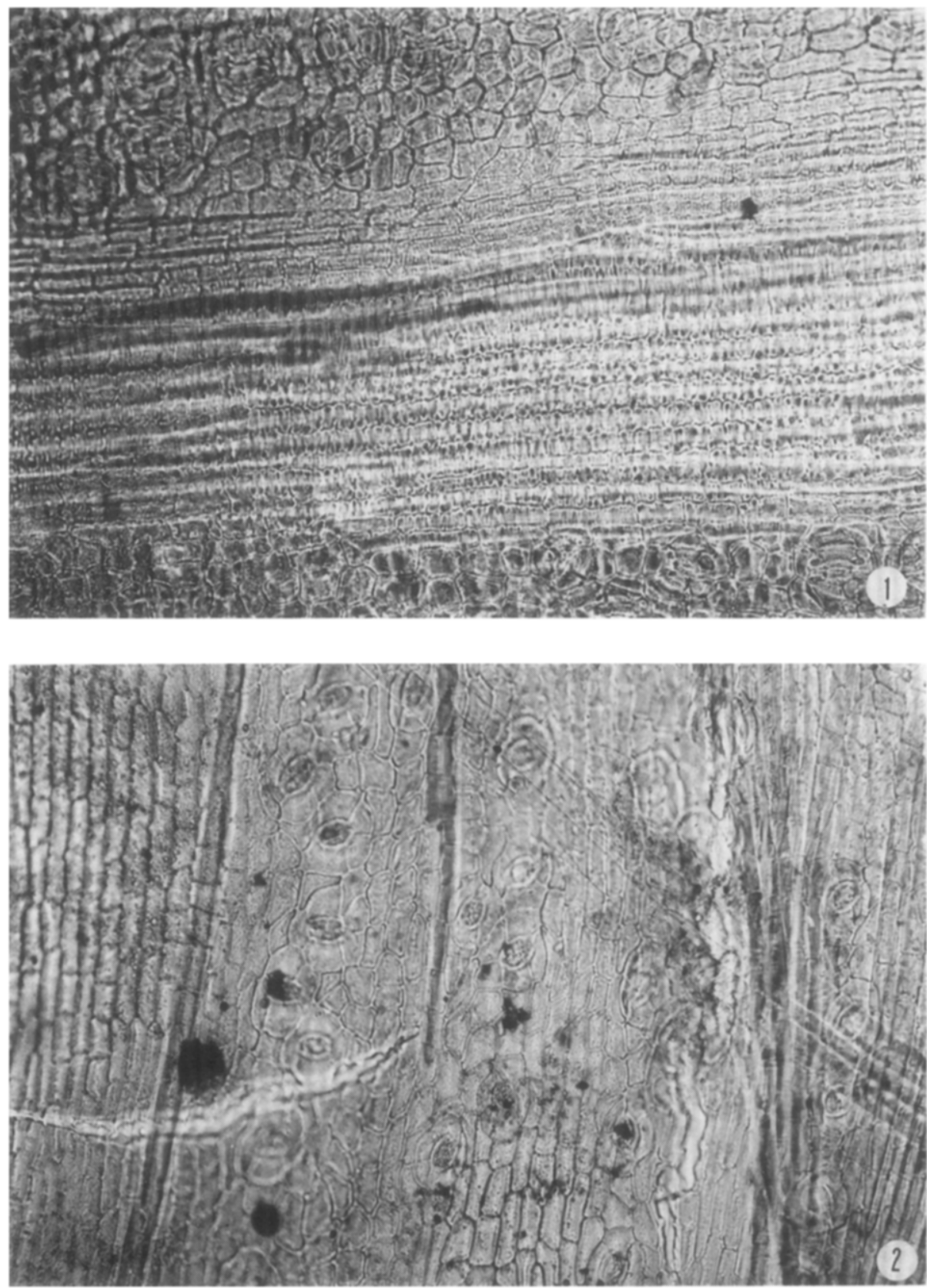

1. Sequoia sempervirens (D. Don) Endlicher, slide no.509, cuticle showing two stomatal bands and one non-stomatal band, $\times 200$.

2. Cryptomeria japonica D. Don, slide no.465, cuticle showing several converging stomatal bands, the midrib is on the left, $\times 200$. 


\section{DISCUSSION}

According to Selley (1975) these Jurassic shales of Sutherland belong to a subwave-base marine shale deposit, influenced by a nearby delta. Thus, the leaf impressions can be interpreted as transported from the land by rivers which shed their load into the sea, where it was dispersed and finally sedimented. Consequently we may expect a strong influence from the flora of the river delta. This is suggested by the similarity with the flora of the older Yorkshire deltaic beds. Of the twenty taxa described in this paper, eight occur also in the Yorkshire Jurassic plant beds, whilst four of them have near-relatives there, in total 12 taxa or $60 \%$ of the flora.

Whereas the influence of the sea was not very high in the Yorkshire deposits, this may be expected to be substantially greater in our deposit, where much material from the lower and thus more strongly marine-influenced regions of the delta is deposited. The younger Wealden deposits in Western Europe consist of a facies of low-lying land, with fresh-water deposits alternating with marine intercalations. The flora of these younger deposits is also similar to our flora: Six of the twenty taxa occur also in the Wealden deposits and five have near-relatives there, in total eleven taxa or $55 \%$

\section{TABLE I}

Numbers of fossils per taxon and their representation in five vegetational types

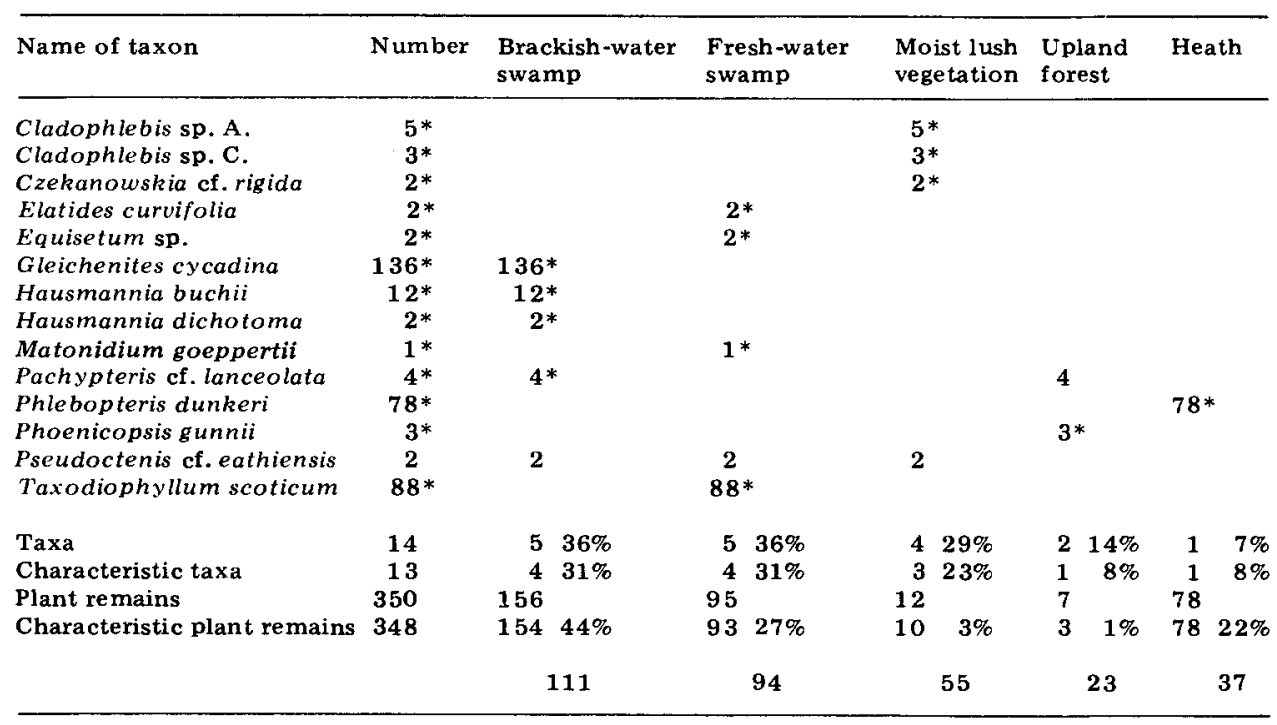

Taxa: sum of all taxa found; characteristic taxa: sum of all taxa considered characteristic for any one of the vegetations mentioned (all figures with an asterisk); plant remains: sum of all plant remains; characteristic plant remains: sum of all plant remains, belonging to characteristic taxa.

The figures in the bottom line are obtained by adding the percentages: low figures: 0-30; medium figures: $31-60$; high figures: $61-300$. See also van der Burgh (1983). 
Thus, from the geological record and from the similarity of floras it can be concluded that the flora came from a partly low-lying delta.

A count of the material in situ has been made. If we divide the taxa according to their ecology, using the method described by one of the authors (Van der Burgh, 1983), we obtain the following result (Table I): high figures for brackish swamps and fresh-water swamps, medium figures for moist, lush vegetation and heath and a low figure for upland forest. The comparatively high figure for heath (in comparison to the figure for upland forest) is possibly the effect of the preservation of the fossils; the leaves of Phlebopteris are fusainised and therefore no longer subject to decay. Also the floating capacity of fusain can be well marked and these together must have resulted in a wide distribution of easily recognisable leaf fragments of this fern.

Without comparing this flora with other floras from the same region, treated in the same way, the question of the ecological relations of the plants and the making of the landscape is difficult to answer in more detail. Future research on the material of Culgower may throw some light on this.

\section{REFERENCES}

Andrae, K.L., 1853. Fossile Floren Siebenburgens und des Banates. Abh. K.K. Geol. Reichsanstalt, $2: 1-48$.

Appert, D., 1973. Die Pteridophyten aus dem oberen Jura des Manamana in SüdwestMadagaskar. Schw. Paläontol. Abh., 94:1-62.

Barale, G., 1975. Etude préliminaire des genres Cycadopteris Zigno, 1853 et Lomatopteris Schimper, 1869. Geobios, 8(37): 181-184.

Barale, G., 1981. La Paléoflore jurassique du Jura français: Etude systématique, aspectes stratigraphiques et paléontologiques. Documents des Lab. de Géol., Lyon, 8: $467 \mathrm{pp}$.

Barale, G., 1982. Le genre Cycadopteris Zigno au Jurassique dans l'ouest Européen. Palaeontographica, B 183: 8-56.

Barnard, P.D.W., 1965. Flora of the Shemshak formation. Part 1. Liassic plants from Durod. Riv. Ital. Palaeontol., 71(4): 1123-2268.

Carpentier, A., 1927. La flore Wealdienne de Féron-Glageon. Mém. Soc. Géol. Nord, 10: $1-151$.

Clement-Westerhof, J.A., 1984. Aspects of Permian palaeobotany and palynology. IV. The conifer Ortiseia Florin from the Val Gardena Formation of the Dolomites and the Vicentian Alps (Italy) with special reference to a revised concept of the Walchiaceae (Göppert) Schimper. Rev. Palaeobot. Palynol., 41: 51-166.

Doludenko, M.P., 1974. On the relation of the genera Pachypteris, Thinnfeldia and Cycadopteris. In: Symp. Morphological and Stratigraphical Palaeobotany, Spec. publ. 2, Lucknow, pp.8-16.

Doludenko, M.P. and Svanidze, T.I., 1969. The late Jurassic flora of Georgia. Trans. Acad. Sci. U.S.S.R., 178: 1-116.

Doludenko, M.P. and Rasskazova, E.S., 1972. Ginkgoales and Czekanowskiales of the Irkutzk basin. Trans. Acad. Sci. U.S.S.R., 230: 7-43.

Doludenko, M.P. and Orlovskaya, E.R., 1976. Jurassic flora of the Karatau. Trans. Acad. Sci. U.S.S.R., 284: 1-260.

Dunker, W., 1846. Monographie der Norddeutschen Wealdenbildung. Dehmke und Müller, Braunschweig, 48 pp.

Florin, R., 1936. Die fossilen Ginkgophyten von Franz-Josephland nebst Erörterungen über vermeintliche Cordaitales mesozoischen Alters, I. Spezieller Teil. Palaeontographica, B 81: 71-173. 
Fontaine, W.M., 1889. The Potomac or younger Mesozoic Flora. Monogr. U.S. Geol. Surv., 15: 1-377.

Harris, T.M., 1935. The fossil flora of Scoresby Sound, East Greenland. Part 4 : Ginkgoales, Coniferales, Lycopodiales and isolated fructifications. Medd. Gronl., 112(1): 1-176.

Harris, T.M., 1961. The Yorkshire Jurassic Flora, I. Thallophyta-Pteridophyta. British Museum (Nat. Hist.), London, 211 pp.

Harris, T.M., 1964. The Yorkshire Jurassic Flora, II. Caytoniales, Cycadales and Pteridosperms. British Museum (Nat. Hist.), London, $191 \mathrm{pp}$.

Harris, T.M., 1979. The Yorkshire Jurassic Flora, V. Coniferales. British Museum (Nat. Hist.), London, $166 \mathrm{pp}$.

Harris, T.M., 1981. Burnt ferns from the English Wealden. Proc. Geol. Assoc., 92: 47-58.

Harris, T.M. and Rest, J.A., 1966. The flora of the Brora coal. Geol. Mag., 103(27): 101109.

Harris, T.M., Millington, W. and Miller, J., 1974. The Yorkshire Jurassic Flora, IV. Ginkgoales and Czekanowskiales. British Museum (Nat. Hist.), London, 150 pp.

Krassilov, V.A., 1972. Mesozoic Flora of the Bureja Basin (Ginkgoales and Czekanowskiales). Akad. Nauk S.S.S.R., Moskow, 150 pp.

Lam, K. and Porter, R., 1977. The distribution of palynomorphs in the Jurassic rocks of the Brora outlier, N.E. Scotland. J. Geol. Soc. Lond., 134: 45-55.

Lovis, J.D., 1975. Aspidistes thomasii, a Jurassic member of the Thelypteridaceae. Fern Gazette, 11: 137-140.

Nathorst, A.G., 1897. Zur mesozoischen Flora Spitzbergens. K. Sven. Vet. Akad. Handl., Stockholm, 30(1): 1-77.

Oishi, S. and Yamasita, K., 1936. On the fossil Dipteridaceae. J. Fac. Sci. Hokkaido Imp. Univ., Sapporo, (4) 3: 135-184.

Reymanówna, M., 1963. The Jurassic flora from Grojec near Cracow in Poland. Acta Palaeobot., 4(2): 9-48.

Richter, P.B., 1906. Beiträge zur Flora der unteren Kreide Quedlinburgs I. Die Gattung Hausmannia Dunker und einige seltene Pflanzenreste. Leipzig, 25 pp.

Samylina, V.A., 1972. Systematics of the genus Phoenicopsis. In: V.A. Vachrameev (Editor), Mesozoic Plants (Ginkgoales and Czekanowskiales) of East Siberia. Publ. Acad. Sci. U.S.S.R., Trans., $230: 44-81$.

Schenk, A., 1871. Die fossile Flora der Nordwestdeutschen Wealdenformation. T. Fischer, Kassel, $66 \mathrm{pp}$.

Selley, A.C., 1975. The habitat of North Sea oil. Proc. Geol. Assoc., 87: 359-389.

Seward, A.C., 1911. The Jurassic flora of Sutherland. Trans. R. Soc. Edinb., 47 (4) no.23: 643-709.

Seward, A.C. and Bancroft, N., 1913. Jurassic Plants from Cromarty and Sutherland, Scotland. Trans. R. Soc. Edinb., 48: 867-888.

Stopes, M.C., 1907. The flora of the Inferior Oolte of Brora (Sutherland). Q. J. Geol. Soc. London, 63: 375-382.

Tralau, H., 1966. Botanical investigations in the fossil flora of Eriksdal in Fyledalen, Scania. Sv. Geol. Unders., Ser. C, 611:1-36.

Vachrameev, V.A., Dobruskina, I.A., Meyen, S.V. and Zaklinskaya, E. D., 1978. Paläozoische und mesozoische Floren Eurasiens und die Phytogeographie dieser Zeit. Gustav Fischer Verlag, Jena, 300 pp.

Van der Burgh, J., 1983. Allochthonous seed and fruit floras from the Pliocene of the lower Rhine basin. Rev. Palaeobot. Palynol., 40:33-90. 